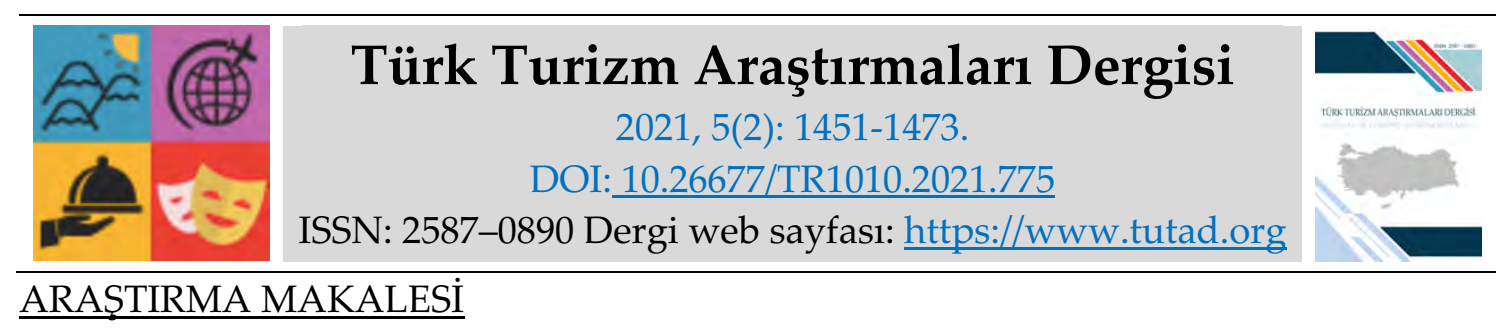

\title{
Paydaşların Bakış Açısıyla Muğla İli Sağlık Turizmi*
}

Cesim DALAN, Yüksek Lisans Öğrencisi, Muğla Sıtkı Koçman Üniversitesi, Sosyal Bilimler Enstitüsü, Muğla, e-posta: cesimdalan@mu.edu.tr

ORCID: https://orcid.org/0000-0001-6510-7026

Doç. Dr. Işıl ARIKAN SALTIK, Muğla Sıtkı Koçman Üniversitesi, Fethiye İşletme Fakültesi, Muğla, e-posta: isilas@mu.edu.tr

ORCID: https://orcid.org/0000-0002-3456-2787

\section{Öz}

Sağlık turizmi, tatil ve tedavi hizmetlerinin bütünleştirilmesiyle bireylerde zihinsel ve bedensel iyileştirmeyi amaçlayan turizm faaliyetlerini kapsamaktadır. Tüketicilerin turizm anlayışlarındaki ve taleplerindeki değişimlerin yanı sıra, bilim ve teknolojideki ilerlemeler doğrultusunda sağlık turizmi gelişmekte ve yaygınlaşmaktadır. Bu çalışmanın amacı, sağlık turizmi paydaşları olarak nitelendirilen sağlık kurum ve kuruluşları, turizm işletmecileri, sivil toplum kuruluşları ve yerel yönetim temsilcilerinin bakış açılarıyla Muğla ilinin sağlık turizmi potansiyelinin incelenmesidir. Böylelikle, Muğla'da sağlık turizmi paydaşlarının konuyla ilgili genel düşüncelerinin, sağlık turizmine önem verme durumlarının, sağlık turizmi kapsamında nitelendirilebilecek uygulamalarının ve sağlık turizm konusundaki beklentilerinin belirlenmesi hedeflenmektedir. Nitel araştırma yöntemleriyle gerçekleştirilen araştırmada, maksimum çeşitlilik örnekleme benimsenmiştir. Görüşme tekniğiyle 19 kişiden toplanan veriler betimsel analiz ile incelenmiştir. Araştırma sonucunda sağlık turizmi paydaşlarının sağlık turizmine önem verdikleri ve özellikle olumlu ekonomik etkileri nedeniyle gelişimini destekledikleri belirlenmiştir. Paydaşlar, Muğla'nın sağlık turizmi potansiyelini yüksek olarak değerlendirmekle birlikte, altyapı ve üstyapı eksiklikleri nedeniyle hak ettiği konuma erişemediğini düşünmektedirler. Araştırma sonucunda, sağlık turizminin sürdürülebilir gelişimi için konuyla ilgili uygulayıcılara ve araştırmacılara öneriler sunulmuştur.

*Cesim DALAN'ın yüksek lisans tezinden üretilen bu çalışma, 22-24 Ekim 2020 tarihleri arasında düzenlenen 4th Congress of International Applied Social Sciences (C-iasoS 2020) Kongresinde "A Qualitative Research To Evaluate Health Tourism Potential” başlıklı bildiri olarak sunulmuştur.

Anahtar Kelimeler: Turizm, Sağllk Turizmi, Muğla.

Makale Gönderme Tarihi: 20.03.2021

Makale Kabul Tarihi: 02.06.2021

Önerilen Atıf:

Dalan, C. ve Arıkan Saltık, I. (2021). Paydaşların Bakış Açısıyla Muğla İli Sağlık Turizmi, Türk Turizm Araştırmaları Dergisi, 5(2): 1451-1473.

(C) 2021 Türk Turizm Araştırmaları Dergisi. 


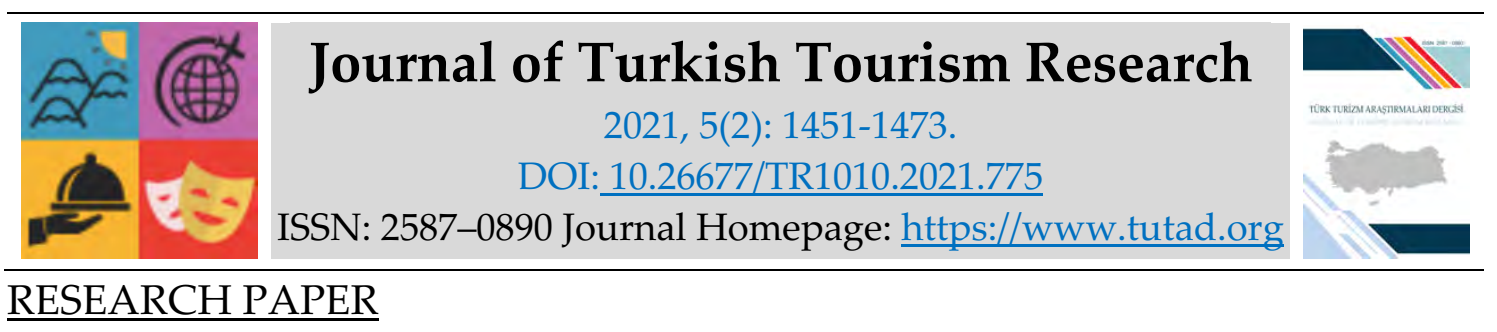

Health Tourism in Muğla through Stakeholders' Perspective

Cesim DALAN, MSc. Student, Muğla Sıtkı Koçman University, Social Sciences Institute, Muğla, e-mail: cesimdalan@mu.edu.tr ORCID: https://orcid.org/0000-0001-6510-7026

Associate Prof. Dr. Işıl ARIKAN SALTIK, Muğla Sıtkı Koçman University, Fethiye Business School, Muğla, e-mail: isilas@mu.edu.tr ORCID: https://orcid.org/0000-0002-3456-2787

\begin{abstract}
Health tourism is consisted of tourism activities aiming at mental and physical healing in individuals by integrating holiday and treatment services. In addition to changes in tourism understanding and demands of consumers, health tourism develops and spreads in line with advances in science and technology. Aim of this study is to examine health tourism potential of Muğla province from perspectives of health tourism stakeholders, namely the representatives of health institutions, tourism businesses, non-governmental organizations and local government. In this way, it is aimed to determine general thoughts of health tourism stakeholders in Muğla on subject, their status of giving importance to health tourism, practices that can be described within scope of health tourism and their expectations about health tourism. In the research conducted with qualitative research methods, maximum diversity sampling was adopted. Data collected from 19 people using interview technique were analyzed by descriptive analysis. As a result of research, it was determined that health tourism stakeholders attach importance to health tourism and support its development especially due to its positive economic effects. Stakeholders consider that Muğla can't reach position it deserves due to its deficiencies in infrastructure and superstructure, although they evaluate health tourism potential of Muğla as high. As a result of research, suggestions were provided to relevant practitioners and researchers for sustainable development of health tourism.
\end{abstract}

Keywords: Tourism, Health Tourism, Muğla.

Received: 20.03.2021

Accepted: 02.06.2021

\title{
Suggested Citation:
}

Dalan, C. and Arıkan Saltık, I. (2021). Health Tourism in Muğla through Stakeholders' Perspective, Journal of Turkish Tourism Research, 5(2): 1451-1473.

(C) 2021 Türk Turizm Araştırmaları Dergisi. 


\section{Gíriş}

Turizm, ekonomik, toplumsal ve kültürel etkileri nedeniyle uluslararası düzeyde önem taşıyan bir sektördür. Tüketicilerin turizm anlayışlarındaki ve taleplerindeki değişimlerin yanı sıra, bilim ve teknolojideki ilerlemelerle turizm faaliyetleri de gelişmekte ve çeşitlenmektedir. Bu kapsamda, öne çıan turizm çeşitlerinden birisi, tatil ve tedavi hizmetlerinin bütünleştirilmesiyle bireylerde zihinsel ve bedensel iyileştirmeyi amaçlayan sağlık turizmidir (Dünya Turizm Örgütü, 2018). Son yıllarda dünya nüfusunun hızla yaşlanması, tüketici tipinin farklılaşması, yılın her döneminde uygulanabilmesi gibi nedenlerle sağlık turizmine olan ilgi artmaktadır. Türkiye sahip olduğu 1.300 termal kaynak ile dünyada yedinci, Avrupa'da ise birinci sırada yer almakta, ileri düzey teknolojilerle donatılmış hastaneleriyle, doğal ve kültürel güzellikleriyle sağlık turizmi pazarında öne çıkma potansiyeline sahip ülkeler arasındadır.

Muğla, Türkiye'nin önemli turizm merkezlerinden birisi ve aynı zamanda uluslararası bir turizm destinasyonudur. Muğla'da gerçekleştiren turizm faaliyetlerinin deniz-kum-güneş turizmi kapsamında geliştiği bilinmekle birlikte, son yıllarda alternatif turizm kapsamında yer alan turizm faaliyetlerinin de gerçekleştiği görülmektedir (Muğla İl Kültür ve Turizm Müdürlügü̈, 2019). Sağlık turizmi açısından değerlendirildiğinde, Muğla'da görece sınırlı sayıdaki uygulamanın genel anlamda tekil girişimcilik faaliyetleri olarak gerçekleştirildiği görülmektedir. Diğer yandan Muğla'da, özellikle yüksek sezon olarak adlandırılan dönemlerde taşıma kapasitesinin üzerinde ziyaretçi gelişi nedeniyle turizmin ekonomik, sosyo-kültürel ve çevresel anlamda olumsuz etkileri daha yoğun bir şekilde yaşanmaktadır. Belirtilen unsurlar, Muğla'da turizmin mevsimsellik özelliğinin azaltılması, turizmden elde edilen gelirin ve adil dağıtımının arttırılması ve sürdürülebilir turizm anlayışı çerçevesinde farklı uygulamalarla pazar bölümünün yenilenmesi ve yeni hizmetlerin geliştirilmesi gerekliliğini göstermektedir. Bu bağlamda Muğla ilinde sağlık turizmi, bu konuda etkin olabilecek, turizm sektörünün ülke ve yöre ekonomisine katkısını arttırabilecek bir uygulama alanı olması nedeniyle önem taşımaktadır. Çalışmada, yazında görece sınırlı incelenmiş olan Muğla ili sağlık turizmi potansiyelinin çeşitli paydaşların görüşleri alınarak toplanan derinlemesine bilgi üzerinden değerlendirilmesi amaçlanmaktadır. Çalışmada öncelikle sağlık turizmi ve gelişimi hakkında bilgi verilmekte, ardından araştırma yöntemi açıklanmaktadır. Çalışma, araştırma bulgularının değerlendirilmesi ve konuyla ilgili araştırmacı ve uygulayıcılara sunulan önerilerle tamamlanmaktadır.

\section{KAVRAMSAL ÇERÇEVE}

Teknolojide yaşanan ilerlemeler, telekomünikasyon ve ulaşımda yaşanan gelişmelerin yanı sıra sağlık sektöründeki gelişmeler, insan yaşamının uzaması, bireylerin sağlık konusunda daha fazla bilgi sahibi olmaları sağlık hizmetlerinin gelişmesini ve sağlık hizmetlerine yönelik talebi artırmaktadır. Sağlık maliyetlerindeki artışlardan ötürü çoğu devlet, bazı sağlık giderlerini sigorta kapsamindan çıkartmakta ve sigorta sistemlerinde özelleştirmeye gitme yolunu tercih etmektedirler. Bu gibi sebeplerden ötürü insanlar daha düşük maliyetlerle tedavi olabilmenin yollarını aramaktadır. Gelişmekte olan ülkelerde sağlık alanına önem verilmesi bu tür arayışlar içinde olan insanları bu destinasyonlara yönlendirmektedir (Tontuş, 2019). Bu bağlamda ortaya çıan sağlık turizmi, sağlığın güçlendirilmesi ve sağlıklı yaşamın devamlılığının sağlanması için meydana gelen ve tatili de içeren seyahatler ve organizasyonları kapsayan durum ve insan ilişkilerinin bütünü olarak tanımlanabilir (Gençay, 2007). Son zamanlarda dünyada insanların tatil programlarını yaparken klasik tatil anlayışı yerine sağlık hizmetleri sunan tesisleri seçme yönünde eğilim sergiledikleri görülmektedir (Uygun, 2018: 7) 
"Sağlık turizmi, sağlığın yeniden kazanılması ve iyileşme, wellness olarak adlandırılan iyi olma durumu ve sağlık ile tıbbi bakım hizmetlerini kapsamaktadır. Özel bakım hizmeti veren ve belli bir hastalık için yararlı hizmet sunan tesis ya da bölgeler, kilo kontrol kliniği ya da spa gibi spor yapma, diyet yapma, zayıflama gibi koruyucu sağlık uygulamaları için hizmet veren tesis ya da bölgeler, belirli bir hastalığa diğer sağlık merkezlerinden farklı bir tedavi uygulayan ünlü klinikler gibi tesisler bu hizmetlerin verildiği yerleri oluşturmaktadır" (Dünya Turizm Örgütü, 2018). Sarışık'a (1994) göre sağlık turizmi, insanların belirli bir süre için (en az 21 gün) ikamet ettikleri yerden ayrılıp doğal kaynakları barındıran bir destinasyona giderek yeme, içme, konaklama ve hastalıklarını tedavi etme sonucunda oluşan hareketlerdir. Tablo 1'de uluslararası ve ulusal kuruluşlar tarafından yapılmış sağlık turizmi tanımları özet olarak sunulmaktadır.

Tablo 1. Uluslararası ve Ulusal Kuruluşların Sağlık Turizmi Tanımları

\begin{tabular}{|c|c|c|}
\hline Kurum Adı & Tarih & Sağlık Turizmi Tanımı \\
\hline $\begin{array}{l}\text { Uluslararası } \\
\text { Resmi Seyahat } \\
\text { Birliği (IUOTO) }\end{array}$ & 1972 & $\begin{array}{l}\text { Sağlı̆̆ı koruma ve iyileştirme amacı ile belirli bir süre yer } \\
\text { değiştiren bireylerin, doğal kaynaklara dayalı turistik bir tesise } \\
\text { giderek konaklama, dinlenme yeme-içme, eğlenme, dinlenme ve } \\
\text { kür uygulamasına benzer ihtiyaçların giderilmesi faaliyetidir. }\end{array}$ \\
\hline $\begin{array}{l}\text { Türkiye Sağlık } \\
\text { Turizm Rehberi }\end{array}$ & 2009 & $\begin{array}{l}\text { Tedavi maksadı ile yapılan seyahatlerdir. Fiziksel ve/veya mental } \\
\text { anlamda tedaviye gereksinim duyanlarla beraber uluslararası } \\
\text { hasta potansiyelini kullanarak sağllk kuruluşlarının gelişmesine } \\
\text { imkân tanıyan turizm türü olarak tanımlanır. }\end{array}$ \\
\hline $\begin{array}{l}\text { T.C. Kültür ve } \\
\text { Turizm } \\
\text { Bakanlığ } 1\end{array}$ & 2014 & $\begin{array}{l}\text { Sağlık turizmi tedavi olmak için şifalı su kaynaklarına, sağlık } \\
\text { merkezlerine seyahat eden bireyin bedensel durumunu } \\
\text { geliştirme ya da estetik operasyonlar, diş tedavisi organ nakli, } \\
\text { rehabilitasyon, fizik tedavi vb. ihtiyaçları olanlarla beraber } \\
\text { uluslararası hasta potansiyelini kullanarak sağlık kuruluşlarının } \\
\text { büyümesine fırsat veren bir turizm çeşidi olarak tanımlanır. }\end{array}$ \\
\hline $\begin{array}{l}\text { T.C. Sağlık } \\
\text { Bakanlığ } 1\end{array}$ & 2018 & $\begin{array}{l}\text { Sağlık turizmi, insanları koruyan, tedavi eden, rehabilite eden ve } \\
\text { sağlığı geliştiren hizmetleri satın almak amacıyla yaşanılan } \\
\text { ikametgâhtan ayrılıp başka ülkelere yapılan seyahatlerdir. }\end{array}$ \\
\hline $\begin{array}{l}\text { Dünya Turizm } \\
\text { Örgütü } \\
\text { (UNWTO) }\end{array}$ & 2018 & $\begin{array}{l}\text { Sağlık turizmi, tıbbi ve sağlıklı yaşam temelli faaliyetler } \\
\text { aracllığıyla fiziksel, zihinsel ve / veya manevi sağlığa katkısı olan } \\
\text { temel motivasyonu olan turizm türlerini kapsamaktadır. }\end{array}$ \\
\hline
\end{tabular}

Yukarıdaki tanımlardan ışığında sağlık turizmi, bireyin yaşadığı yerden başka bir destinasyona giderek orada bulunan sağlık hizmetlerinden yararlanması ve bu süreçte sağlık hizmetine ek olarak ulaşım, konaklama ve serbest zamanı değerlendirme seçeneklerinin bir arada sunulduğu turizm ürün ve hizmetlerinden yararlanmasıyla gerçekleşen turizm türü şeklinde ifade edilebilir.

Günümüzde ilgi odağı haline gelen ve hızla gelişmeye devam eden sağlık turizmi esasında yeni bir olgu değildir, yeryüzündeki en eski turizm biçimlerinden biridir. Tarih boyunca zenginler tarafından yapılan bireysel geziler, modern anlamda olmasa da sağlık turizmin ilk örnekleri olarak kabul edilebilir (Yirik, 2014). Bu kapsamda medeniyetlerin varoluşundan günümüze kadar termal su kaynaklarının sağlık hizmetlerinde tedavi edici özelliklere sahip olduğu ve bu amaca yönelik olarak kullanıldığı anlaşılmaktadır (Tontuş, 2019). Sümerler döneminde 
kaplıcaların çevresinde devasa büyüklükte tapınakları barındıran spor tesisleri (Gymnasium), Antik Yunan döneminde Yunan tıp tanrısı adına kurulan, dünyadaki ilk sağlık merkezlerinden Asclepia tapınakları, Romalılar döneminde tedavi ve eğlence amacıyla kullanılan termal sular, Osmanlı dönemindeki şifahane ve kaplıcalar, 20. yüzyılda Amerika ve Avrupa'da modern tıp hizmetine erişmek üzere gerçekleştirilen uluslararası seyahatler, 21. yüzyılda Asya'da daha ekonomik tedavi olanaklarına ulaşmak üzere gerçekleştirilen uluslararası sağlık turisti hareketlilikleri geçmişten günümüze gerçekleştirilen sağlık turizmi faaliyetlerindendir.

Sağlık turizmi denildiğinde akla ilk gelen kaplıcalar, içmeler, şifalı sular olmakla birlikte; sağlık turizmi sadece bunlarla sınırlı değildir. Sağlık turizmi çeşitli çalışmalarda farklı biçimlerde sınıflandırılmaktadır. Bu sınıflandırmalar içinde klimatizm, üvalizm, termal turizm, mağara turizmi ve medikal turizm olarak adlandırılan sağlık turizmi çeşitleri yer almaktadır. Sağlık Turizm Daire Başkanlığına göre sağlık turizmi; tıp veya medikal turizm, termal turizm ile yaşlı ve engelli turizmi olarak üçe ayrılmaktadır. Cohen (2008) ise sağlık turizmini medikal turizm, termal/spa/wellness turizmi, ileri yaş turizmi, engelli turizmi olarak dörde ayırmaktadır.

Medikal turizm, insanların ülke içinde ya da başka ülkelere tıbbi tedavi amacıyla seyahat etmesini ifade etmektedir. Sağlık hizmetleri fiyatlarının yüksek oluşu ve sıra bekleme sürelerinin uzun olması gibi nedenlerden dolayı insanların, tedavi olmak için başka ülkelere seyahat etmelerine medikal turizm denir. Temel amaç, tedavi olmakla birlikte turizm sektörünün sağladığı hizmetlerden konaklama, yiyecek-içecek, ulaşım ve seyahat programlarından yararlanmaktır (Tengilimoğlu, 2013). Bazı kaynaklarda tıp turizmi olarak da adlandırılan medikal turizm, ülkelerin sağlık merkezlerinde belirli planlamalarla doktorların uyguladığı herhangi bir sağlık sorunu olan yerli ve yabancı turistlere ücret karşılığında tedavi maksadıyla yapılan uygulamalardır. Genellikle diş, göz, organ nakli, tüp bebek ve estetik cerrahi gibi hizmetleri barındıran uygulamalardır. Medikal turizm, hizmete ulaşım mesafesini kısaltıp tıbbi hizmeti ulaşılabilir hale getirmektedir. Medikal turizm, farklı ülkelerden, farklı dinlerden, farklı ırklardan insanların katıldığı bir faaliyet olduğu için bu farklı ülkeler arasındaki bağları da güçlendirir. Bu ülkeler arasındaki hasta sirkülasyonu ile karşılıklı bilgi alışverişi artacağından hastane çalışanları daha deneyimli hale gelecektir (Kiremit, 2008). Ayrıca medikal turizm hem ulusal hem de uluslararası alanda faaliyette bulunan, aynı zamanda dünyadaki değişimlerin etkisinde kalan ve bu değişimleri etkileyen bir konumdadır (Gray ve Poland, 2008).

Termal turizm, en eski sağlık turizmi türüdür. Termal turizm; bireylerin hastalık ve hastalıklarının tedavisine ek olarak, bireylerin dinlenmeleri ve iyi vakit geçirmeleri için termal su kaynakları olan destinasyonlara gitmelerinin bir sonucu olarak ortaya çıkan bir turizm türüdür (Aslan, 1996). Turizm Bakanlığı (1993) tarafından yayınlanan çalışmaya göre termal turizm bir bölgedeki mineral bakımından zengin termal sular ve çamurlar, o bölgedeki iklim faktörleri ile birlikte bireyin hastalığının iyileşmesi amacıyla alanında kendini kanıtlamış doktorların kontrolünde ve programı kapsamında, fiziksel ve zihinsel destek tedavileri ile paralel kür uygulamak için gerçekleştirilen turizm faaliyetleridir. Termal turizm faaliyetinin gerçekleştiği destinasyonlarda turizm faaliyetleri yıl boyunca devam ettiğinden yatırımcılarına her mevsim kazanma firsatı sunma üstünlügüne sahiptir.

SPA ve wellness turizmi, şifalı sularla yapılan tedaviyi içeren sağlık turizmi türüdür. Spa sadece su ve çamurla terapi hizmeti veren yerler değil, aynı zamanda güzellik ve bakım gibi sağlık hizmeti veren tesislerdir. Uzman kişiler tarafından verilen ve günümüzde oldukça yaygın bir şekilde kullanılan spa-wellness hizmeti, su ve çeşitli kürlerin yardımı ile vücuttaki yorgunluk hissinin azaltılması ve vücudun ağrılardan arındırılmasıdır. Spa turizmi, insan sağlığının geri kazanılması için mineral ya da termal havuzlar ve saunalar gibi su temelli kaynakların kullanılmasıdır (Smith ve Puczko, 2008). 
Illeri yaş veya geriatri turizmi, kendi temel ihtiyaçlarını gideremeyen, başkasının bakımına ihtiyaç duyan ileri yaştaki bireylerin, temel gereksinimlerini temin etmek amacıyla başka destinasyonlara seyahat etmeleriyle gerçekleşmektedir (Çetinkaya ve Zengin, 2009). İleri yaş turizmi, özel ilgi gerektiren en az 65 yaşın üzerinde olan bireylerin tedavi edilmesidir. Üçüncü yaş turizmiyle karıştırılsa da ileri yaş turizmi sadece sağlı̆̆ın düzelmesi için birtakım faaliyetler içerir. İleri yaş turizminin önemli amaçlarından biri ise ileride gerçekleşmesi olası hastalıklara önceden önlemler alınmasını ve bu olası hastalıkların tespit edilmesini sağlamaktır (Gençay, 2007). İleri yaş turizmi, başka bir destinasyona tedavi amacıyla giden bireye tedavi hizmetlerinin yanı sıra gidilen destinasyonda tatil yapma fırsatı tanıdığı için ilgi çekicidir. İleri yaş turizmi yaşlıların ihtiyaçlarına uygun, onların yaşamını geliştirici ve onların yaşamına renk katacak bir sağlık turizmi türüdür (Kabukcuoğlu, 2013).

Engelli turizmi, engellilerin ihtiyaçların gidermek için ikamet ettiği yerden ayrılıp başka bir destinasyona seyahat etmesidir. Turizm destinasyonunun erişilebilir olması ulaşımın, konaklamanın ve diğer faaliyet yerlerinin ulaşılabilir olması demektir. Bu grubun çoğunluğu 65 yaş ve üstü hastalar gibi aktif bir çalışma hayatına sahip olmadığından, düşük sezonlar olarak düşünülen zamanlarda alt yapının, ulaşımın ve koşulların yeterli olduğu yerlere gelip uzun süre konaklama olasılığını bulundururlar (Shelton ve Tucker, 2005). Bu da turizm pazarında önemli bir yeri kapsadıklarının göstergesidir. Genel olarak tercih ettikleri yerler onların ve ailelerinin rahat edebildikleri, her türlü ihtiyaçlarına kolayca cevap alabildikleri alanlar ve tesisler olduklarından bunların sayısının artırılması iki taraf için de olumlu sonuçlar doğuracaktır.

Bireylerin uluslararası sağlık turizmine katılmasının birkaç nedeni vardır. Bireyler, ülkelerindeki gelişmiş sağlık hizmetlerinin ve uzmanlaşmış sağlık personelinin yetersizliği veya eksikliği nedeniyle sağlık turizmine katılabilirler (Kangas, 2010). Bireyler sağlık turizmi yoluyla tedavi sırasında da tatil yapmak isteyebilirler (Gülen ve Demirci, 2012). Kendi ülkelerindeki pahalı sağlık hizmetleri (Akdeve, Balay ve Barca, 2013) veya iklim ve coğrafi nedenlerden dolayı kendi ülkelerinde sınırlı imkanlara sahip kişiler nedeniyle farklı bölgelerdeki turizm faaliyetlerine de katılabilirler (T.C. Sağlık Bakanlığı, 2018). Tüm bunlardan hareketle bireylerin hayata tutunma, kendilerini iyi hissetme, mutlu olma, güzelleşme ve daha kaliteli yaşama isteğiyle sağlık turizmine katıldıkları söylenebilir. Farklı uygulama alanlarına sahip olan sağlık turizmi alt sektörleri ile birlikte düşünülerek değerlendirildiğinde bazı temel faydalara sahip olduğu görülmektedir. Sağlık turizminin temel faydaları arasında maliyet avantajı sağlaması öne çıkmaktadır. Sağlık turistleri, gelişmekte olan ülkelerdeki tıbbi turizm destinasyonlarına seyahatlerinde, kaliteli tıbbi bakım ve tedavinin yanı sıra konaklama hizmetini de daha uygun bir maliyetle alabilmektedir. Sağlık turizmi, bireylere yeni bir destinasyon ve yeni bir kültür keşfetmek için de fırsat yaratmaktadır. Sağlık turizmi, turistlerin yanı sıra ev sahibi toplum için de faydalar yaratmaktadır. Özellikle az gelişmiş ülkelerde ve bölgelerde sağlık turizmi; ekonomik büyüme, döviz kazanımı, yatırım, gelir ve istihdam açısından kaynak olarak görülebilmektedir (Erdoğan, 2018).

Sağlık turizminin faydalı yönlerinin yanında sakıncalı yönleri de bulunmaktadır. $\mathrm{Bu}$ sakıncalardan birisi, sağlık turizmi kapsamı içinde sunulan hizmet veya tedaviler nedeniyle sağlık turistlerinin zarar görmelerinin söz konusu olabilmesidir. Bu konu turistlerin sağlık turizmine bakış açısını da olumsuz duruma getirmektedir. Bir diğer sakınca, hizmet veya tedaviler doğrultusunda sağlık turistlerinde birtakım yan etkilerin gelişebilmesi ve bazı hastalarda ölüme dahi sebep olabilme riskinin bulunmasıdır. Sağlık turizminin başka bir sakıncalı yönü ise, hizmet yahut tedavilerde görülen olumsuzluklar ve/veya taahhüt edilen hizmet sunumunda bulunulmamasının ciddi yasal sorunlar yaşanmasına sebep olabilmesidir (Marlowe ve Sullivan, 2007). 
Ülkemizde sağlık turizmi konusunda rolü, görevi, yetkisi ve sorumlulukları bulunan çeşitli sağlık turizmi paydaşları bulunmaktadır. Sağlık turizminin temel paydaşlarının arasında konuyla ilgili resmi yetki ve sorumluluk sahibi olan Sağlık Bakanlığı, Kalkınma Bakanlığı, Kültür ve Turizm Bakanlığı gibi kamu kurumları; sağlık hizmeti sağlayıcısı olarak kamu ve özel sektörde faaliyet gösteren sağlık kurum ve kuruluşları; turizm hizmeti sağlayıcısı olarak turizm işletmeleri, ulaşım, iletişim ve bilişim sektörü temsilcileri ile seyahat acentaları ve sigorta şirketleri yer almaktadır.

Sağlık turizmi pazarındaki yüksek gelir fırsatı ve sağlık turizmi talebindeki artış nedeniyle uluslararası sağlık hizmetlerinin ve sağlık turizmi gelişiminin hızlandığı anlaşılmaktadır. Dünyada sağlık turizmi uygulayıcılarına bakıldığında sağlık turizmi alanında ilk sıralarda yer alan ülkelerin Tayland, Malezya, AB, Meksika, Güney Afrika, Brezilya, Singapur, Kosta Rika, Almanya ve Hindistan olduğu görülmektedir. Bu ülkelerin ön plana çıkmasının ortak nedenleri, sağlık ve bakım hizmetleri, bölgelere erişilebilirlik, kalifiye personel, sağlam altyapı ve ileri teknolojiler alanlarında yüksek kaliteye sahip olmalarıdır (Demirel ve Ünal, 2011). Dünya Turizm Örgütü ve Avrupa Seyahat Komisyonu (2018: 68-70) tarafından yapılan sıralamaya göre 2015 yılında, sağlıkla ilgili uluslararası seyahatlerden hem en yüksek geliri elde eden hem de en fazla harcama yapan ülke ABD olmuştur. Toplamda 3.598 milyon dolar gelir elde edilen ABD'de, 1.828 milyon dolar harcama yapılmıştır. Sağlık turizminden en yüksek gelir elde etme sıralamasında ABD'yi sırasıyla Türkiye, Ürdün, Fransa, Macaristan, Kore Cumhuriyeti, Tayland, Kosta Rika, Belçika, Meksika, Çek Cumhuriyeti ve Hindistan izlemektedir. Sağlık turizmi harcamalarına ilişkin sıralamaya bakıldığında ise 1.569 milyon ABD doları ile ikinci sırada yer alan Kuveyt'in ardından, sırasıyla Almanya, Nijerya, Belçika, Kanada, Umman ve Fransa gelmektedir. Türkiye'nin en çok harcama yapan 25 ülke arasında yer almamasına karşın, en yüksek gelirler sıralamasında ise ikinci sırada yer alması dikkat çekmektedir (Çeti ve Ünlüönen, 2020).

Türkiye'nin sağlık turizmi gelirleri diğer turizm gelirleri ile karşılaştırıldığında oldukça yüksektir. Ülkenin genel turizm gelirleri içinde sağlık turizminin 2002 yılında \%1,19 olan payı, 2019 yılında yaklaşık 2 katına ulaşarak \%3,08'e ulaşmıştır. Bununla birlikte, Türkiye'nin sağlık turizmi hedeflerinin gerisinde kaldığı belirtilmektedir (Kara, 2020:273). Türkiye'nin, Dünya genelinde sağlık turizmi gelirlerindeki sıralamasıyla ve sağlık turizmi gelirlerinin artışıla uyumlu bir şekilde, Türkiye'ye sağlık amaçlı gelen turist sayısında da yükselen bir trend izlenmektedir. 2003 yılından 2018 yılına kadar olan zaman diliminde sağlık amaçlı gelen turist sayısının \% 294,19 arttığı; turist sayısı içindeki sağlık turisti payının ise \% 40,70 yükseldiği belirtilmektedir. Rakamlar, Türkiye açısından sağlık turizmine olan talebin arttığının göstergesi niteliğindedir (Çeti ve Ünlüönen, 2020).

Türkiye'de sağlık turizminde uluslararası standartlara ulaşmak ve genel koordinasyonu sağlamak amacıyla 2010 yılında Sağlık Turizmi Koordinatörlüğü ve daha etkin gelişmeler yapmak üzere, Sağlık Hizmetleri Müdürlüğü bünyesinde Sağlık Turizmi Daire Başkanlığı kurulmuştur. Türkiye'deki sağlık potansiyelini tüm dünyaya açılamak ve bu konuda istatistiksel bilgi vermek amacıyla bir web sitesi (Sağlık Turizmi Dairesi Başkanlığı, 2010) oluşturulmuştur (Özgül, 2014). Ülkemizde sağlik turizmi söz konusu olduğunda, medikal turizm, termal turizm, spa-sağlıklı yaşam, ileri yaş turizmi ve engelli turizm başlıca konulardır. Ülkemizdeki sağlık kuruluşlarından 48 tanesi JCI ile akredite edilmiş uluslararası standartlardadır. Özellikle İstanbul, Ankara ve Antalya'da bulunan kamu, özel ve üniversite hastaneleri muazzam bir teknoloji ile tam donanımlı hale getirilmiştir. Bu hastaneleri diğer hastanelerden ayıran en önemli özelliklerin başında Cyberknife, robotik cerrahi, MR, hizmetleri, kemik iliği, organ nakli gibi hizmetler vermeleridir. Sağlık Bakanlığı Sağlık Turizmi Dairesi Başkanlığı bünyesinde günün her saati Arapça, İngilizce, Almanca ve Rusça dilinde Acil 
durumlarda 112, şikâyet durumlarında ise 184 numaralı hatlardan ve hastanelerde uluslararası hastalara tercümanlık hizmetleri verilmektedir (Sağlık Turizmi Derneği, 2019).

Sağlık turizmi konusunda uluslararası literatür incelendiğinde, sağlık turizmi konulu çalışmaların son yıllarda artış gösterdiği görülmektedir. 2000'li yılların başlarına kadar sağlık turizminin kapsamına, önemine ve gelişimine ilişkin çalışmaların (Hall, 1992; Goodrich, 1994; Pollock ve Williams, 2000; Mueller ve Kaufmann, 2001) ağırlık gösterdiği, sonrasında ise kavramsal çalışmaların (Garcia-Altes, 2005; Carrera ve Bridges, 2006; Gustavo, 2010; Hofer, Honegger ve Hubeli, 2012; Smith ve Puczkó, 2015; Lee ve Kim, 2015) yanı sıra konuyla ilgili destinasyonların incelendiği araştırmaların da yapılmaya başladığı belirlenmiştir. Jónás-Berki vd. (2015), Macaristan'daki sağlık turizmi destinasyonlarına pazar perspektifi ve mekânsal açıdan baktıkları çalışmalarında, medikal turizm de dahil olmak üzere örnek destinasyonlara odaklanarak ülkede sağllk turizminin kendine has özelliklerini değerlendirmişlerdir. Majeed, Lu ve Javed (2017) çalışmalarında medikal turizmdeki değişiklikleri ile Geleneksel ve Tamamlayıcı Tıp tedavi yöntemlerine olan talepleri incelemiştir. Araştırma sonucunda, doğal tedavilerin sağlık turistleri tarafından olduğu kadar allopatik tedaviler (ameliyatlara ve ilaçlara dayalı geleneksel bir yaklaşım) ve turizm cazibe merkezleri tarafından da düşünüldügü belirlenmiştir. Polonya'daki Spa merkezlerinin incelendiği bir başka çalışmada (Dryglas ve Salamaga, 2018), tıbbi (geleneksel) spa merkezlerini ziyaret eden turistleri bölümlere ayırmak ve onları motive eden altta yatan faktörleri incelemişlerdir. Manna vd., (2019) İtalya genelinde yapılan araştırmadan toplanan ikincil verilere dayanarak, İtalya'daki sağlık turizmini ele almışlardır. Çalışmada İtalya'da sağlık turizminin henüz başlangıç aşamasında olduğu, sağlık turistlerinin genellikle kısa gezileri ve kentsel bölgeleri tercih ettikleri sonucuna ulaşmışlardır. Esfahani, Ridderstaat ve Öztürk (2020) tarafından yapılan çalışmada, ABD'li sağlık turistlerinin gelişmiş bir ülkede (Kanada) oluşturduğu turizm talebinin, sağlıkla ilgili turizm harcamaları üzerindeki etkisini araştırmaktadır. Büyüközkan, Mukul ve Kongar (2021) çalışmalarında analitik tabanlı SWOT analizi ile İstanbul sağlık turizminin güçlü ve zayıf yönlerini, fırsatları ve tehditlerini analiz etmekte ve etkin uygulamalara yönelik en güçlü stratejinin belirlenmesini amaçlamaktadır.

Ulusal literatürde de sağlık turizm konusunda farklı kapsam ve içeriklerde çeşitli çalışmalar yapılmıştır. Türkiye'nin sağlık turizmi sektörünü analiz eden (Akdeve, Balay ve Barca, 2013; Mikail ve Çora, 2020), turizm faaliyetleri içinde sağllk turizminin yeri ve önemini inceleyen (Akdoğan ve Hiçyorulmaz, 2018), Türkiye' de sağlık turizmi konusunda kavram karmaşasını irdeleyen (Kara, 2020), ülkenin sağlık turizmi açısından konumu ve gelişimini değerlendiren (Edinsel ve Adıgüzel, 2014; Sülkü, 2017), sağlık turizminde markalaşma modeli geliştirerek, model önerisini Türkiye üzerinden örneklendiren (Yıldırım, 2020), sağlık turizminin cari işlemler açığının kapatılmasına olan katkısını inceleyen (Işık, Özsezer ve Işık, 2021), Güneydoğu Anadolu Bölgesi özelinde sağlık turizmini inceleyen (Elsaied, Mahmood ve Toprak, 2014) ve medikal turizmin kadın sağlığı üzerine etkilerini araştıran (Aydın ve Yılmaz, 2020) çeşitli çalışmaların olduğu görülmüştür. Bunların yanı sıra sağlık turizmi konulu makalelerin bibliyometrik analizinin yapıldığı (Çiçek vd., 2015) ve turizm rehberliğinde alan uzmanlığı önerisi olarak irdelendiği (Akdu vd., 2018) farklı çalışmalar da gerçekleştirilmiştir.

Bilimsel araştırmaların gelişiminde yüksek lisans ve doktora dereceleri için hazırlanan tezler, özgün bir araştırmayı düzenli ve bilimsel bir bütünlük içinde sunan eserler olduğu için önem taşımaktadır. Bu kapsamda Ulusal tez merkezinden taranarak konuyla ilgili gerçekleştirilmiş lisansüstü tezler incelenmiştir (Ulusal Tez Merkezi, 2019). Buna göre, sağlık turizmi ile ilgili 19922021 yılları arasında 68 tez yazılmış ve son yıllarda konuyla ilgili tez çalışmasında bir artış ortaya çıkmıştır. Lisansüstü tez çalışmalarının ağırlıklı olarak yüksek lisans düzeyinde olduğu, yalnızca 13 adet doktora tezinin yazıldığı görülmüştür. Lisansüstü tez çalışmalarında ağırlıklı olarak; 
sağlık turizmi politikaları, uygulamaları, turizm sağlık ilişkisi, sağlık turizmi hizmetleri, sağlık turizminin ülkemizdeki mevcut durumu gibi konular çalışılmıştır. Tezlerde sağlık turizmi çalışanlarından, hekimlerden veya hastalardan veri toplanmıştır. Buna karşın farklı sağlık turizmi paydaşlarının görüşlerinin alındığı veya Muğla ili sağlık turizmi potansiyeline yönelik bir araştırmanın yapılmadı $\breve{g}$ belirlenmiştir.

\section{ARAŞTIRMANIN YÖNTEMI}

$\mathrm{Bu}$ çalışmanın amacı, sağlık turizmi paydaşlarının bakış açılarıyla Muğla'nın sağlık turizmi potansiyelinin incelenmesidir. Böylelikle, Muğla'da sağlık turizmi paydaşlarının konuyla ilgili genel düşüncelerinin, sağlık turizmine önem verme durumlarının, sağlık turizmi kapsamında nitelendirilebilecek uygulamalarının ve sağlık turizm konusundaki beklentilerinin belirlenmesi hedeflenmektedir.

Çalışmada, sosyal bilimlerde en sık kullanılan yöntemlerden biri olan nitel araştırma yöntemi tercih edilmiştir. Bu tercihte, Muğla ilinde araştırmanın konusu olarak belirlenen sağlık turizmi ile ilgili çok sayıda çalışma yapılmamış olması da etkili olmuştur. Nitel araştırma bireyin yaşadığı dünyayı nasıl anlamlandırdığı ile ilgili bir anlayış ortaya koyarak, bu anlamlandırma aşamalarının temel esaslarını belirlemek ve bireyin yaşadıklarını nasıl yorumladı̆̆ını açılamaktır (Merriam, 2013). Gözlem, görüşme ve doküman analizi gibi nitel bilgi toplama yöntemlerinin kullanılarak, algıların ve olayların doğal ortamda gerçek ve bir bütün olacak biçimde ortaya çıkarılmasına yönelik nitel bir sürecin takip edildiği araştırma, nitel araştırma olarak tanımlanmaktadır (Yıldırım ve Şimşek, 2016). Nitel araştırma yönteminde elde edilen veriler, temel veri olarak kullanılmaktadır. Ayrıca, nitel araştırmalarda elde edilen sonuçlar ışığında, sağlık turizmi üzerinde daha kısa sürede değerlendirilebilen ve farklı paydaşlardan daha fazla veri toplanarak ölçek geliştirme ve uygulama araştırmaları yapılabilmektedir.

Araştırma verilerinin toplanmasında yarı yapılandırılmış görüşme tekniği kullanılmıştır. İki bölümden oluşan görüşme formunda ilk olarak görüşme yapılan kişiye ve temsil ettiği kuruma ilişkin bilgileri edinmeye yönelik 10 soru bulunmaktadır. İkinci bölümde, araştırmanın amacı doğrultusunda, görüşme yapılan kişilerin sağlık turizmi ile ilgili görüş, değerlendirme ve önerilerini belirlemeye yönelik 5 soru yer almaktadır. Katılımcılara sorulan araştırma soruları, araştırmaya konu olan problemin soru olarak ifade edilmiş tarzıdır. Araştırmanın soruları, araştırmanın bütün basamaklarını etkileyen öğelerden biridir (Yıldırım ve Şimşek, 2013). Sağlık turizmiyle ilgili ulusal ve uluslararası literatür incelenerek, araştırma konusuna uygun olacak görüşme soruları belirlenmiştir. Görüşme soruları bir akademisyen, bir sağlık kurumu yöneticisi ve bir turizm işletmesi yöneticisine iletilerek önerileri doğrultusunda düzenlemeler yapılmış ve böylelikle uzman görüşü alınarak nihai halleri oluşturulmuştur. Araştırma kapsamında sorulan temel sorular aşağıda sıralanmaktadır:

1. Sağlık turizmi hakkında düşünceleriniz nelerdir?

2. Muğla'nın sağlık turizmi potansiyeli konusunda düşünceleriniz nelerdir?

3. Muğla'da sağlık turizmi faaliyetlerinin etkileri konusundaki düşünceleriniz nelerdir?

4. Temsilcisi olduğunuz kurum/kuruluşun yürüttüğü sağlık turizmi faaliyetleri hakkında bilgi verir misiniz?

5. Sağlık turizmi faaliyetlerinden beklentileriniz nelerdir?

Araştırmada, amaçlı örnekleme yöntemleri arasında maksimum çeşitlilik örneklemesi tercih edilmiştir. Bu sayede göreceli olarak küçük bir örneklem meydana getirmek ve örneklemde 
üzerine çalışılan probleme taraf olabilecek insanların farklılıklarını en fazla derecede yansıtmaktır (Yıldırım ve Şimşek, 2013). Araştırmanın amacı doğrultusunda sağlık turizmi hakkında bilgi ve fikir sahibi olması öngörülen sağlık turizmi paydaşları olarak kabul edilen kurum ve kuruluşların yetkilileri örneklemi oluşturmaktadır. Araştırma kapsamında; (i) sağlık kurum ve kuruluşları, (ii) turizm işletmeleri, (iii) sivil toplum kuruluşları ve (iv) yerel yönetimler olmak üzere dört temel grup sağlık turizmi paydaşı olarak belirlenmiştir. Grupların belirlenmesindeki temel faktör, sağlık turizmine farklı perspektiflerden bakacak ve sağlık turizmi uygulamaları açısından farklı nitelik ve şartlara sahip kurum ve kuruluşların çeşitlendirilmesi olmuştur. Araştırma kapsamında yer alan sağlık turizmi paydaşları Şekil 1'de görsel olarak sunulmuştur.

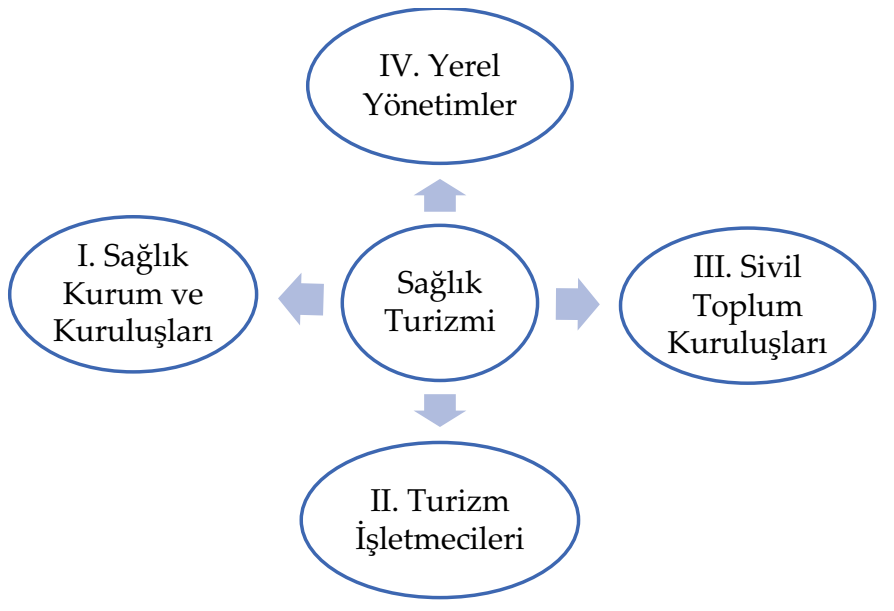

Şekil 1. Sağlık Turizmi Paydaşları

Araştırma verileri, Mart ve Nisan 2019 arasında farklı gruplarda sağlık turizmi paydaşlarını temsil eden toplam 19 kişiyle yüz yüze görüşmeler yoluyla toplanmıştır. Görüşmelerin tamamı görüşme yapılan kişilerin talepleri doğrultusunda kendi işyerinde gerçekleştirilmiştir. Böylelikle görüşme yapılan kişilerin kendilerini daha rahat ve konforlu hissetmesi sağlanmıştır. Görüşmeler şeffaflık içinde tamamlanmıştır. Nitel araştırmalarda geçerlik ve güvenilirliğin yüksek olması için öznellikten uzak durulmalıdır (Guba ve Lincoln, 1994). Bu çalışmada araştırılan olgu olduğu gibi tarafsız bir gözle aktarılmıştır. Görüşme sorularına alınan yanıtların birbirini tekrar etmeye başlaması ve araştırma konusuyla ilgili yeni bir bilgiye ulaşılmamaya başlanması başka bir deyişle doyum noktasına ulaşılması nedeniyle görüşmeler sonlandırılmıştır. Ortalama 30 dakika süren görüşmeler sonunda edinilen alan notları, bilgisayar ortamında metin haline dönüştürüldüğünde toplam 31 sayfalık metin elde edilmiştir. Araştırma verileri betimsel analiz ile incelenmiştir. Betimsel analizin amacı, verilerin özgün anlamlarına sadık kalınarak elde edilen bulguların okuyucunun anlayacă̆ı biçimde sunulmasıdır (Yıldırım ve Şimşek, 2013). Bu bağlamda bu çalışmada görüşmeler sonucunda elde edilen bilgiler sistematik olarak düzenlenerek okuyucunun kolaylıkla anlayabileceği bir şekilde sunulmaktadır. Ayrıca, bulgular kapsamında bazı katılımcıların konuya ilişkin görüşleri de doğrudan alıntı halinde verilmektedir.

\section{BULGULAR}

Araştırma kapsamında yarı yapılandırılmış görüşme tekniği ile veri toplanan kişilere ait tanımlayıcı bilgiler Tablo 2' de sunulmaktadır. 
Tablo 2. Katılımcların Tanımlayıcı Bilgileri

\begin{tabular}{|l|c|c|c|c|c|}
\hline & Cinsiyet & Yaş & Medeni Durum & Aylık Gelir (TL) & Eğitim Durumu \\
\hline K1 & Kadın & 38 & Evli & 4.500 & Lisans \\
\hline K2 & Erkek & 35 & Evli & 4.000 & Yüksek Lisans \\
\hline K3 & Erkek & 38 & Evli & 12.000 & Doktora \\
\hline K4 & Erkek & 46 & Evli & 15.000 & Lisans \\
\hline K5 & Erkek & 47 & Evli & 10.000 & Doktora \\
\hline K6 & Erkek & 37 & Evli & 4.000 & Lisans \\
\hline K7 & Kadın & 37 & Evli & 4.500 & Ön Lisans \\
\hline K8 & Erkek & 37 & Evli & 6.500 & Lisans \\
\hline K9 & Kadın & 34 & Bekâr & 3.000 & Ön Lisans \\
\hline K10 & Erkek & 39 & Evli & 4.000 & Ön Lisans \\
\hline K11 & Erkek & 46 & Evli & 10.000 & Ön Lisans \\
\hline K12 & Erkek & 50 & Evli & 5.000 & Lisans \\
\hline K13 & Erkek & 54 & Evli & 20.000 & Doktora \\
\hline K14 & Erkek & 56 & Evli & 4.000 & Lisans \\
\hline K15 & Erkek & 32 & Evli & 10.000 & Yüksek Lisans \\
\hline K16 & Erkek & 43 & Evli & 6.000 & Lisans \\
\hline K17 & Erkek & 35 & Bekâr & 10.000 & Doktora \\
\hline K18 & Erkek & 58 & Evli & 10.000 & Yüksek Lisans \\
\hline K19 & Erkek & 35 & Evli & 4.000 & Lisans \\
\hline
\end{tabular}

Çalışma kapsamında görüşülen kişiler çoğunlukla erkek $(n=17)$ ve evlidir $(n=17)$. Yaşları 32 ile 58 arasında değişmekte olup yaş ortalaması $39^{\prime}$ dur. Aylık ortalama gelirleri 7.710 bin TL olarak hesaplanan katılımcılarının tamamının, ön lisans ile doktora düzeyi arasında değişmekle birlikte, üniversite mezunu olduğu belirlenmiştir. Bu durum sağlık turizmi faaliyetlerinde karar verici ve uygulayıcı konumunda olan kurum ve kuruluşların temsilcilerinin eğitim düzeylerinin yüksek olduğunun, dolayısıyla nitelikli işgücü özellikleri taşıdığının bir göstergesi olarak değerlendirilebilir. Katılımcıların temsil ettikleri kurum ve kuruluşlara ait tanımlayıcı bilgiler Tablo 3'te sunulmaktadır.

Katılımcıların 8'i sağlık kurum ve kuruluşlarını, 5'i turizm işletmelerini, 2'si sivil toplum kuruluşlarını, 4'ü ise yerel yönetimleri temsil etmektedir. Temsil ettikleri sağlık turizm paydaşlarının nitelikleri, farklı paydaşların görüşlerini temsil edecek şekilde çeşitlilik göstermektedir. Faaliyet yerleri açısından dağılımları incelendiğinde Menteşe $(n=5)$, Fethiye $(n=4)$, Marmaris ( $n=3)$, Bodrum ( $n=3)$, Köyceğiz $(n=2)$, Milas $(n=1)$ ve Ortaca $(n=1)$ olmak üzere il genelinde faaliyet gösteren farklı paydaşların yer aldığı görülmektedir. 
Tablo 3. Katılımcıların Kurumsal Bilgileri

\begin{tabular}{|l|l|l|c|l|c|}
\hline & $\begin{array}{l}\text { İşletmenin Faaliyet } \\
\text { Alanı ve Türü }\end{array}$ & Görev/ Departman & $\begin{array}{l}\text { Paydaş } \\
\text { Grubu }\end{array}$ & $\begin{array}{l}\text { Faaliyet } \\
\text { Yeri }\end{array}$ & $\begin{array}{l}\text { İşletme } \\
\text { Yaş1 }\end{array}$ \\
\hline K1 & Sağlık- Hastane & $\begin{array}{l}\text { Hemşire / Uluslararası Hasta } \\
\text { Birimi }\end{array}$ & PI & Muğla & 92 \\
\hline K2 & Sağlık- Hastane & $\begin{array}{l}\text { Yabancı Hasta Danışmanı / } \\
\text { Uluslararası Hasta Birimi }\end{array}$ & PI & Fethiye & 22 \\
\hline K3 & Sağlık- Hastane & Doktor / Yabancı Hasta Birimi & PI & Fethiye & 22 \\
\hline K4 & Sağlık-Diş Hekimi & Diş Hekimi & PI & Marmaris & 19 \\
\hline K5 & Sağlık- Hastane & Doktor & PI & Fethiye & 11 \\
\hline K6 & Otel İşletmeciliği & Spa Sorumlusu / Spa & PII & Bodrum & 4 \\
\hline K7 & Otel İşletmeciliği & Müdür / İnsan Kaynakları & PII & Marmaris & 8 \\
\hline K8 & Turizm- Kaplıca & İşletme Müdürü & PII & Köyceğiz & 40 \\
\hline K9 & Turizm- Otelcilik & Spa süpervizör / Wellness Spa & PII & Bodrum & 25 \\
\hline K10 & Yerel Yönetimler & $\begin{array}{l}\text { Şube Müdürü / Sağlık } \\
\text { Hizmetleri }\end{array}$ & PIV & Muğla & 5 \\
\hline K11 & $\begin{array}{l}\text { Sivil Toplum } \\
\text { Kuruluşu }\end{array}$ & Meslek Komitesi Üyesi & PIII & Fethiye & \\
\hline K12 & Yerel Yönetimler & Şube Müdürü / Tanıtma Şubesi & PIV & Muğla & \\
\hline K13 & Sağlı- Hastane & Doktor / Başhekim & PI & Milas & 12 \\
\hline K14 & Turizm İ̧letmesi & Teknik Eleman & PI & Köyceğiz & 2 \\
\hline K15 & $\begin{array}{l}\text { Sivil Toplum } \\
\text { Kuruluşu }\end{array}$ & Yönetici & PIII & Bodrum & \\
\hline K16 & Otel İşletmeciliği & Otel Müdürü / Satış Pazarlama & PII & Ortaca & 15 \\
\hline K17 & $\begin{array}{l}\text { Sivil Toplum } \\
\text { Kuruluşu }\end{array}$ & Başkan & PIII & Marmaris & 9 \\
\hline K18 & Sağlık- Hastane & Doktor / Dekan & Muğla & 4 \\
\hline K19 & Yerel Yönetimler & $\begin{array}{l}\text { Tercüman / Turizm Şube } \\
\text { Müdürlüğü }\end{array}$ & Muğla & 6 \\
\hline
\end{tabular}

\section{Sağlık Turizmi Paydaşlarının Sağlık Turizmi Hakkında Genel Düşünceleri}

Görüşmeler sonucunda sağlık turizmi paydaşlarının sağlık turizmi hakkında genel bilgi sahibi oldukları anlaşılmıştır. Paydaşlar sağlık turizminin dünya genelindeki gelişimine vurgu yapmış ve Türkiye' de sağlık turizmi faaliyetlerinin yetersiz kaldığına ilişkin düşünceler dile getirilmiştir. Örneğin 2. ve 12. katılımcının konu hakkındaki görüşleri şu şekildedir:

"Basitçe söylemek gerekirse sağlık turizmi, tedavi amaçlı yapılan seyahatlerin, kişinin gereksinimleri doğrultusunda çeşitlilik arz etmesi karşısında sağlık kuruluşlarının, uluslararası hasta taleplerine turizm sektörünün dinamiklerine uygun şekilde cevap vermesidir." (K2-Yabancı Hasta Danışmanı).

"Sağlık turizminin, Dünya turizm hareketleri pastasındaki payının giderek arttığını düşünüyorum. Sağlık turizmi alt türleri içinde medikal turizm kavramını dışarıda bırakmak istiyorum. İyileştirici tıp olanaklarnna yönelik, son çare aramalarnna yönelik zorunlu harcamaları "Turizm Gelirleri" dışında tutmak görüşündeyim. Turizm kavraminda bir istek, bir arzu, bir merak, bir gezme, bir görme iradesi, niyeti olmalıdır. Medikal turizm içinde bu oranın çok küçük olduğunu düşünüyorum. Termal turizm, spa-wellness gibi turizm türlerinde geleceğin çok parlak olduğuna 
inanıyorum. Engelli turizmi ve ileri yaş / üçüncü yaş turizminin alanının ise sağlık turizminden çok daha geniş olduğu düşüncesindeyim" (K12-Yerel Yönetim Temsilcisi).

1. ve 6. katılımclar, ülkemizdeki sağlık turizmi faaliyetlerinin yetersiz kaldığını aşağıdaki şekilde dile getirmişlerdir:

"Ekonomik olarak ciddi bir getiri sağlayan turizm sektörü içerisinde çok düşük dilime sahip olan sağllk turizminin hak ettiği yerde olmadığına inanmaktayım... Dünyanın önemli jeotermal kuşağında bulunmamız nedeniyle mineralli sular açısından zengin ülkeler arasında olmamız bizim için şanstır ve bu şansı iyi değerlendirmekte bizim elimizde" (K1Doktor).

"Dünyada ve ülkemizde sağllk turizmi son yıllarda hızla yükselen bir trend olup çok önemli bir alternatif turizm çeşididir. Ancak ülkemizde hak ettiği yerde olmadığın düşünüyorum." (K6-Spa Müdürü).

\section{Sağlık Turizmi Paydaşlarının Muğla'nın Sağlık Turizmi Potansiyeli Hakkındaki Düşünceleri}

Sağlık turizmi paydaşları Muğla'nın sağlık turizmi potansiyelini olumlu etkileyen güçlü yanları ve olumsuz etkileyen zayıf yanları hakkında görüş beyan etmişlerdir. Paydaşlar; Muğla'nın sağlık turizmi kapsamında en güçlü yanlarının; sahip olduğu doğal güzellikleri, yer altı kaynakları, uluslararası bir turizm destinasyonu niteliği taşıması, çok sayıda nitelikli turizm tesisinin bulunması ve ulaşım kolaylığı olduğunu düşünmektedirler. Muğla ilinde sağlık turizminin güçlü yanlarına 11. ve 4. katılımcılar aşağıdaki şekilde değinmişlerdir:

"İlimizin 2 havaalanı ve birçok limanı sahip olması, İklim ve doğası, mevcut turizm tesislerinin her bütçeye uygun ve çok kaliteli oluşu, global tur operatörlerinin hali hazırda bölgemizde faaliyet gösteriyor olması, İlimizde kaliteli hastanelerin bulunması" (K11-STK Temsilcisi).

"Muğla sağllk turizmiyle tatili birleştirmek isteyen yabancilar için cazip bir seçenektir. Tabii ki uygun iklim ve temiz hava yapısı avantajdır. Ayrıca hazır ve yeterli yatak kapasitesi ve yetişmiş personel ile özellikle konaklama sorununun olmaması artıdır" (K4-Diş Hekimi).

Ayrıca, sağlık turizmi paydaşlarına göre Muğla, coğrafi konumdan ötürü de sağlık turizmi için avantajlı bir alt yapıya sahiptir. Denizin ve ormanlık bölgelerin iç içe olması, erişilebilir bir konumda olması ve sahip olduğu iklim, sağlık turizmi için Muğla'ya önemli bir üstünlük sağladığı belirtilmiştir. Örneğin 12. ve 16. katılımcılar Muğla'nın sağlık turizmi alanında iklim ve konum bağlamındaki avantajlarını şu şekilde ifade etmiştir:

"Yeşil coğrafyası, bol oksijeni, koyları, denizleri, kaplıcaları, çamur banyoları sağlık turizmi ve özellikle de ileri yaş, üçüncü yaş turizmi için idealdir" (K12-Yerel Yönetim Temsilcisi).

"İklimi, havayolu, ulaşım kolaylı̆̆ı, kaliteli konaklama tesisleri, tedarikçiler" (K16-Otel Müdürü).

Muğla'nın sağlık turizmi potansiyelini olumsuz etkileyen unsurlar da dile getirilmiştir. Paydaşlara göre Muğla'da reklam ve tanıtım eksikliği, alt yapı yetersizliği, alanında yeterli sayıda uzman hekimin olmaması ve yeterli derece konaklama işletmesinin olmamasını sağlık turizminin zayıf taraflarıdır. Örneğin 9. ve 11. katılımcılar Muğla ilinin sağlık turizmi için dezavantajlı yönlerine aşağıda sözlerle değinmişlerdir:

"Genel anlamda Muğla bölgesinin sadece turizm şehri olarak tanınması ve să̆llk turizmi için yeterli alt yapısinin olmaması" (K9-Spa Müdürü).

"Bölgemiz kitle turizmde çok yüksek potansiyele sahip olması nedeniyle sağllk turizmine yeterli yatırım ve ilgi olmayabilir, Alt yap yapılmadan (arıtma, yol, çöp bertaraf) yapılacak özellikle yeni yatırımlarda çevre ve doğa tahribatı olması" (K11-STK Temsilcisi). 
Bununla birlikte Muğla'nın sağlık turizmi için hiçbir olumsuz unsurun söz konusu olmadığını belirten katılımcılar da söz konusudur:

"Zayıf yönlerinin olduğunu düşünmüyorum" (K14-Apiterapi Uzmanı)

Sağlık turizmi paydaşlarına göre sağlık turizmi alanında Muğla'nın en büyük dezavantajlı yapısı yeterli miktarda sağlık kurumunun olmaması ve ilçelerin birbirlerine olan uzaklıklarından dolayı bu kurumların her bölgede yapılamamış olmasıdır. Aynı zamanda mevsimsel turizm ön plana çıkartılarak sağlık turizmi alanında belirli bir konsept yaratılamamış olması Muğla'yı bu bağlamda dezavantajlı konuma düşürmektedir. Örneğin 1., 5., 6. ve 15. katılımcılar Muğla'nın tesis yetersizliği ve sağlık turizmi alanındaki plansız yapılanmasını şu şekilde ifade etmektedir:

"Tehdit olarak değil ancak dikkat çekme açısından turistlerin birçoğu denize girmek ve eğlenme amaçlı gelme arzusu içerisinde oldukları için sağllk turizmini biraz gölgede bırakabilir" (K1Doktor).

"Sağglık turizmine hizmet verecek hastanelerin olmaması. Muğla'nın sadece turizm şehri olarak bilinmesi" (K5-Doktor).

"Tesislerin hala yeterli sayıda olmaması, satış ve pazarlamanın yetersiz oluşu, ziyaretçi profili ve destinasyon imajinın farklı olması" (K6-Spa Müdürü).

"Illçeleri arası çok mesafe olması, sağlık turizmi planlarınken her bölgeye özel bir sağlık turizm konsepti geliştirilmeli, ilçeler birbirleriyle ayn konseptlerde să̆lık turizmi yapmamalı. Şu an ki sağllk kurumlarının ve tesislerin sağlık turizmine elverişli olmaması" (K15-STK Temsilcisi).

\section{Sağlık Turizmi Paydaşlarının Muğla'da Sağlık Turizmi Faaliyetlerinin Etkileri Hakkında Düşünceleri}

Görüşmelerde, Muğla'da sağlık turizmi faaliyetlerinin olumlu ve olumsuz etkileri hakkında bulgular edinilmiştir. Sağlık turizmi paydaşları, Muğla ilinde gerçekleştirilecek sağlık turizmi uygulamalarının destinasyonun imajını geliştirmede, marka değerini arttırmada, tanıtımında, ziyaretçi profilinin değişiminde, turizmin çeşitlendirilmesinde, turizm işletmelerinde ve yeni yatırımcılar çekmede olumlu etkilerinin olacağını dile getirmişlerdir. Bu konu hakkında 3., 6. ve 15. katılımcının görüşleri şu şekildedir.

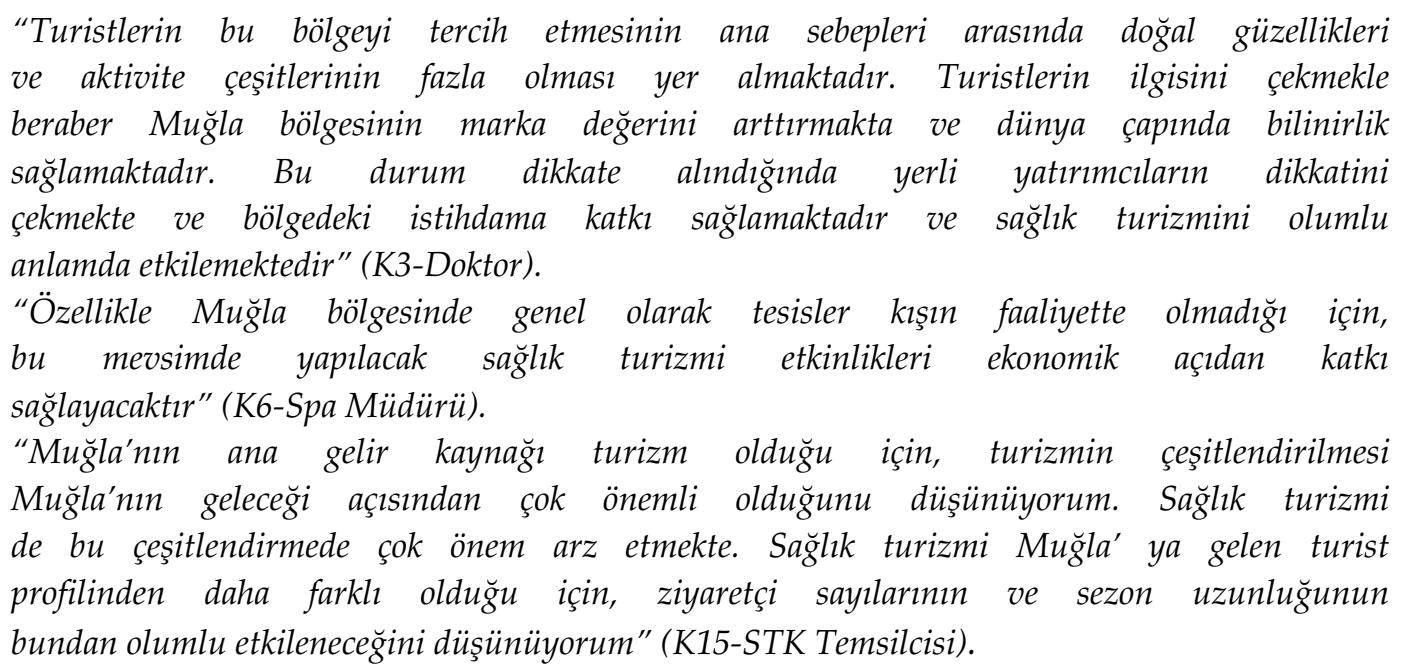

Sağlık turizmi paydaşları sağlık turizminin, Muğla'da faaliyet gösteren sağlık kurum ve kuruluşlarının hizmet ağını geliştirme, dinamikliğini arttırma, gelirlerini yükseltme, personelini geliştirme, sağlık hizmeti kalitesinin iyileşmesi gibi konulara katkı sağlayacağını düşünmektedir: 
"Muğla'da faaliyet gösteren özel ve kamu sağllk kurum ve kuruluşların mali profillerini düzeltmede olumlu etkisi olur" (K13-Doktor)

"Sağllk turizmi her sektörü olumlu etkiler, insanin geldiği noktada ekonomik canlanma olur. Sağlık turizminden de en çok çıkar sahibi olacak kuruluşlar sağlık kurumlarıdır. Çünkü sağlı turizminin de çeşitlenesi bu sağllk kurumlarının kendilerini geliştirmeleri ve daha alternatifli hizmet vermesiyle mümkün olacaktır" (K15- STK Temsilcisi)

Muğla'da yaşayan yerel halkın sağlık turizminden ekonomik ve sosyo-kültürel anlamda olumlu etkileneceği belirtilmiştir:

“...Ekonomik olarak gelen her misafirin muhakkak yerel işlemelere faydası da olacaktır. Özellikle sağhlk amaçl gelecek turistlerin yerel işletmeler için, deniz-kum-güneş orjinli misafirden daha fazla girdi sağlayabileceği kanaatindeyim" (K17-STK Temsilcisi).

"Diğer turizm türlerinde olduğu gibi sağllk turizminin de istihdam üzerinde önemli katkısı vardır. Yöre halkına bu vesileyle başka kültürleri tanıma firsatı doğar ve diğer ülkelerdeki bireylerle kültür alışverişinde bulunulur" (K9-Spa Yöneticisi).

Muğla'da sağlık turizmi faaliyetlerinin genel anlamda olumlu etkileyeceği düşüncesi hakimdir. Bununla birlikte, sağlık personelinin genel anlamdaki yetersizliğinden kaynaklı sıkıntılar yaşanabileceğini ve kontrollü hareket edilmesi gerekliliğini ifade eden paydaşlar olmuştur:

"Hali hazırda ülke genelinde hekim yetersizliğinden dolayı özel ve kamu sağlık kurum ve kuruluşlarına daha da yük bineceği, hastalara ayrilan zamanın daralacağı düşüncesindeyim" (K19-Yerel Yönetim Temsilcisi).

"...Yeni işletmeler kontrolsüz şekilde kurulabileceğinden şehrin yapısıyla ilgili bozulmalara neden olabilir" (K10-Yerel Yönetim Temsilcisi).

Bazı katılımcılar ise sağlık turizminin Muğla'da faaliyet gösteren sağlık kurum ve kuruluşlarını olumsuz etkileyeceğini belirtmiştir:

"Mevcut sağlık personeli çalışanlarının yetersizliği ve üzerlerine düşen günlük ortalama hasta sayısının artmasından dolayı muayene kalitesinin düşeceğini düşünüyorum" (K19-Yerel Yönetim Temsilcisi).

Görüldüğü üzere paydaşlar, sağlık turizminin, Muğla'da faaliyet gösteren turizm işletmeleri, sağlık kurum ve kuruluşları, Muğla'da yaşayan yerel halk ve genel olarak Muğla destinasyonu üzerindeki etkileri hakkında görüşlerini paylaşmıştır. Paydaşların sağlık turizminin etkilerini daha fazla olumlu olarak algıladıkları, sınırlı sayıda katılımcının ise olumsuz etkilerine de değindiği görülmektedir.

\section{Sağlık Turizmi Paydaşlarının Sağlık Turizmi Uygulamaları}

Muğla'da sağlık turizmi uygulamalarının, sağlık turizmi alanında faaliyet gösteren kurumlarda hastalarından gelen talepler doğrultusunda faaliyetlerine başlatmış oldukları görülmektedir. Bu konuda 4.katılımcı şunları ifade etmiştir:

“... Hastaların kendi istekleriyle oluştu. Önce acil durumlarla başlayıp sonradan tavsiye ve sosyal medya gruplarında kendi gruplarındaki yorumlarla talepler hep hastalar tarafindan gelmektedir. Biz sadece hastaların istekleri ve taleplerini hakkıyla karşıladık ve hızla yaygınlaştı..." (K4-Diş Hekimi).

Sağlık turizmi yapabilmek adına bu kurumların yetki belgesi başvurusu yaptıkları ve bu konuda çalışmalarını hızla sürdürdüğü görülmüştür. Bazı katılımcıların bu bağlamdaki söylemleri şu şekildedir: 
"Çalıştığım kurum sağlık turizmi yapabilmek için yetki belgesi müracaatında bulundu ve gerekli şartların yerine getirebilmesi için canla başla çalışmalarımız devam etmektedir" (K1-Doktor).

"Oldu, sağ lık turizmi yetki belgesi aldık, yurt dışından hastalarımız tedavi hizmeti satın almak için bizi tercih ediyorlar" (K13-Doktor).

Bu soruya alınan yanıtların ağırlıklı olarak belgelendirme sürecine ilişkin olduğu, strateji olarak planlanarak yürütülmeye başlanmış sağllk turizmi faaliyetinin daha sınırlı olduğu görülmüştür. Bununla birlikte bazı katılımcılar kurumlarında sağlık turizmi faaliyetlerinin gerçekleştirilmesine yönelik temennilerini dile getirmiştir.

"Kurumumuzda sağlı turizmi faaliyetlerinin olmasını isterdim. Nedeni ise kurumumuzun sezonluk yerine yıl boyu hizmet vererek sezonluk çalışan personellerin 12 ay tesiste çalışabilmelerine imkân sunacağından ve sağlık turizmi için gelecek misafirlerimize 12 ay boyunca hizmet verebilmek" (K9-Spa Yöneticisi).

\section{Sağlık Turizmi Paydaşlarının Sağlık Turizminin Geleceğine İlişkin Beklentileri ve Önerileri}

Sağlık turizmi paydaşları genel olarak Muğla'da sağlık turizmi faaliyetlerinin gerçekleştirilmesini istemektedirler. Hatta bunun bir zorunluluk olduğunu dile getiren katılımcı da olmuştur:

"Tabi ki sağllk turizmi faaliyetlerinin gerçekleştirilmesini isterim. Sezonun uzamasında ve ekonominin gelişmesinde, turizmin çeşitlendirilmesinde önemli rol oynayacağın düşünüyorum. Fakat bunun için tesislerimizin gerekli yatırımlara ihtiyaçları var, bunları yapmakta ciddi bütçeler istemekte, bunula ilgili eğer teşvikler getirilirse daha hızlı ve kolay geçiş yapılabilecektir" (K15-STK Temsilcisi).

"Sağlık turizmin gerçekleşmesi ve geliştirilmesi bir istek değil zorunluluktur. Ekonomik şartların zorlaştı̆̆l dönemlerde ülke ve kuruluşlar için bir kurtuluş bir umuttur" (K4-Diş Hekimi).

Sağlık turizmi paydaşları ayrıca sağlık turizmi faaliyetlerinin gerçekleşmesi için işbirliklerinin gerekliliği konusunda da görüş bildirmişlerdir. Bazı katılımcılardan aşağıdaki şekilde cevaplar alınmıştır:

"Üniversite ilgili birimleri (Tıp Fakültesi, Sağllk Bilimleri

Fakültesi, Turizm Fakültesi) Il Sağllk Müdürlüğ̈̈, Il Kültür ve Turizm Müdürlüğ̈̈, Sektör

Temsilcileri iş birliği ile çeşitli etkinlikler yapabilirler" (K12-Yerel

Yönetim Temsilcisi).

"Yerel yönetimlerin sağlık turizmi ile ilgili olarak il kültür turizmi ile koordineli çalışarak sağlı turizmi potansiyelinin ortaya çıkarılması" (K10-Yerel

Yönetim Temsilcisi)

Sağlık turizmi paydaşlarının sağlık turizminin destinasyona katkısının artması için öncelikle bir üstyapının oluşturulması, sağlık kurumlarının sayısının arttırılması, tanıtım ve bilgilendirme faaliyetlerinin düzenlenmesi ve yabancı dil bilen personel sayısının artması vurgulanmıştır. Konu ile ilgili bazı katılımcıların düşünceleri şu doğrultulardadır:

"Kesinlikle içinde uzmanlarm ve akademisyenlerin olduğu bir kurulun oluşturulması gerekmektedir. Yurt içi ve yurt dışındaki başarılı örneklere bir ekipçe araştırılmalı, Beklentiler iyi analiz edilip, yeni teknolojik yatırmmlarla süreç yönetilmelidir" (K11-STK Temsilcisi). 


\begin{abstract}
“Öncelikle sağlık kurum ve kuruluşlarının sayı ve kalitesinin arttırılması. Sağlık turizmi turları ve destinasyonları oluşturulmalı. Sağlık turizmi olanakları yurtiçilyurtdışı fuarlarda, sosyal medyada, internette ve özel spesifik etkinliklerde tanıtılmalı" (K12-Yerel Yönetim Temsilcisi)

"Öncelikle iyi ürünler çıkarmak gerektiğine inanıyorum. Insanlar neden bölgeye gelecek? Nasıl gelecek ve kalış süreleri boyunca diğer destinasyonlara göre hangi avantajlar olacak? Asgari bu sorulara cevap verecek çok daha kapsamlı çalışmalar olması lazım. Konaklama işletmesi olarak bizim tabi ki burada bir misyonumuz olacak ancak öncelikli olarak kamu ve sağglk sektörünün daha etkin olması gerektiğini düşünüyorum" (K17-STK Temsilcisi).

"Yabancı dil bilen personel sayısının artması, tanıtım faaliyetlerine ağırlık verilmesi ve sektörler arası iş birliğinin tesisi" (K2-Yabancı Hasta Danışmanı).
\end{abstract}

Sağlık turizmi paydaşlarının sağlık turizminin risklerini/olumsuz etkilerini azaltmaya yönelik eğitimlerin verilmesi, planlı programlı hareket edilmesi, iş birliğiyle hareket edilmesi, alt yapının uygun hale getirilmesi vurgulanmıştır. Sağlık turizminin risklerini ve olumsuzluklarını azaltmaya yönelik görüşler ise şöyle sıralanmaktadır:

“Alternatif ürünler oluşturalım derken eldeki mevcut ürünü arka plana koymamak lazım. Muğla bölgesi bir tatil bölgesi ve güçlü bir tatil bölgesi bu imaja zarar vermemeye dikkat edilmesi gerektiğini düşünüyorum" (K17-STK Temsilcisi).

"Planl, programlı ve memnuniyet odaklı bir yapı kurulursa hiç kimsenin yaptığ işi problemli ve eksik yapacağın düşünmüyorum. Eğer müşteri memnuniyet esaslı bir yapı kurulursa riskler minimize olacaktır" (K15-STK Temsilcisi).

"Mevzuatın sık değişmesinin önüne geçilmesi, sektörün gelişmesi noktasında kahıcı çözümler sunulması, teşvikin arttırılması" (K2-Yabancı Hasta Danışmanı)

\title{
SONUÇ ve ÖNERILLER
}

Son yıllarda dünya genelinde yaygınlaşmaya başlayan ve Türkiye' de görece yeni gelişmekte olan sağlık turizmi konusunda Muğla ilinin potansiyelinin belirlenmesi bu çalışmanın temel amacını oluşturmaktadır. Araştırma sonucunda, Muğla ilindeki sağlık turizmi paydaşlarının sağlık turizmi hakkında farkındalığa sahip oldukları anlaşılmıştır. Bu farkındalık, paydaşların sağlık turizmi hakkında genel bilgi sahibi olmasından kaynaklanmaktadır. Sağlık turizmi paydaşlarının, sağlık turizminin gelişimine ilişkin olumlu bir yaklaşım sergiledikleri belirlenmiştir. Bu sonuç Antalya sağlık turizmi potansiyelinin değerlendirildiği (Yalçın, 2013) ve Yirik (2014) tarafından yapılan çalışmaların sonuçlarıyla uyum göstermektedir. Paydaşların ağırlıklı olarak sağlık turizminin ekonomiye olan olumlu etkileri hakkında fikirlerini beyan ettikleri görülmüştür. Bu durum sağlık turizminin ekonomik bağlamda bölgeye katkı sunduğuna ve aynı zamanda istihdam alanlarının gelişmesine yönelik önemli bir unsur olarak görüldüğüne işaret etmektedir.

Sağlık turizmi paydaşlarının temsilcileri, dünya genelinde sağlık turizminin gelişimi hakkında bilgi sahibi olduğu için Türkiye ile dünyayı karşılaştırmış, Türkiye'de sağlık turizminin yeterli olmadığı, geliştirilmesi için gereken önemin verilmediğini ifade etmişlerdir. Araştırma sonuçları, Türkiye'nin sağlık turizminin hiçbir bölümünde uluslararası pazarda istenilen konumu elde etmediği sonucunu belirten Özsarı ve Karatana (2013) ile Daştan (2014) tarafından yapılan çalışmaların sonuçlarıyla örtüşmektedir. Bu durum sağlık turizmi alanında görev alanların, dünya kültürünü ve sağlık turizminin dünyadaki konumunu takip ettiklerini göstermekte ve diğer yerlerdeki uygulama modellerinden hareketle Türkiye'deki uygulama alanlarını geliştirmeye yönelik çaba gösterdiklerine işaret etmesi açısından önem taşımaktadır. 
Muğla ilinin yerüstü doğa güzelliklerine, zengin yeraltı kaynaklara sahip olması, ulaşılabilir uluslararası destinasyon niteliği taşıması, ziyaretçilerin ihtiyaç duyduğu nitelikli hizmetleri verebilecek yeterli tesislerin bulunması vb. özelliklerinin yanı sıra, iklim ve coğrafi konumu sayesinde sağlık turizminin gerçekleştirilmesine oldukça elverişli olduğu belirlenmiştir. Araştırma sonuçları, Türkiye'de sağlık turizminin potansiyelini inceleyen Şahin ve Şahin'in (2018) çalışma sonuçlarıyla uyum göstermektedir. Bu sonuç, sağlık turizminin gerçekleştirilebilmesinde öncelik olarak bölgenin coğrafi konumu, doğa yapısı ve ikliminin önemli tercih nedenleri arasında olduğunun bir göstergesi niteliğindedir.

Sağlık turizmi uygulamaları açısından bu denli elverişli şartlara sahip olan Muğla; reklam, tanıtım, altyapı, uzman hekim ve elverişli işletmelerin yetersiz olmasından dolayı sağlık turizminde ön plana çıkamamaktadır. Ayrıca sağlık turizmi alanında belirli bir konsept yaratılamamış olması Muğla'yı bu bağlamda dezavantajlı konuma düşürmektedir. Muğla'da sağlık turizminin önündeki en büyük engellerden birisi de yeteri kadar sağlık kurumunun olmamasıdır. Bu eksikliğin yanı sıra ilçelerin birbirine olan uzaklıkları da bir dezavantaj yaratmaktadır. Bu sonuç, Şahin ve Şahin'in (2018) çalışmalarında ifade edilen sağlık turizmi hizmeti sunabilecek uluslararası niteliğe haiz hastane zinciri sayısının azlığı ve sağlık turizmine ilişkin lojistik hizmetlerin koordinasyonun yetersizliği sonucu ile uyum göstermektedir. Bu durum sağlık turizmi alanında ilgili bölgenin reklamının daha fazla yapılmasının ve ulaşım altyapısının daha kullanışlı şekilde planlanmasının çok önemli bir unsur olduğuna işaret etmektedir.

Araştırma sonucunda, genel olarak paydaşların sağlık turizmi faaliyetlerinin gerçekleştirilmesini istediği belirlenmiştir. Sağlık turizmi paydaşları, geliştirilebilir ve sürdürülebilir bir turizm anlayışı için uygulanabilir işbirlikleri hakkında da olumlu görüş bildirmişlerdir. Bu durum birlikte hareket etmenin, ulusal veya uluslararası destek alıp, tanıtım faaliyetlerini gerçekleştirmek açısından iş birliği yapmanın gerekliliğini göstermektedir. Muğla'nın sağlık turizmi destinasyonu haline gelmesi için bir üstyapının oluşturulması, kurum sayılarının ve niteliklerinin arttırılması, tanitım ve enformasyon faaliyetlerinin etkin hale getirilmesi, yabancı dil bilen yetişmiş personel altyapısının sağlanması gerekmektedir. Bu kapsamda sağlık turizmi konusunda üniversite liderliğinde ve başarılı sağlık turizmi uygulamalarını da kapsayan eğitsel faaliyetler yürütülmesinin gerekliliği ortaya çıkmaktadır. Bu sonuç, Edinsel ve Adıgüzel'in (2014) çalışmalarında belirttikleri sağlık turizmi alanında eğitimin artırılması, yeni neslin sağlık turizmi sektörüne yönlendirilmesi ve bu alandaki eksikliğin giderilmesi gerekliliği sonucunu desteklemektedir.

Sağlık turizmini geliştirmek adına öncelikle kısa ve uzun vadeli planların hazırlanması, Muğla bölgesinde ve yurtiçinde sağlık turizmi hakkında bilgilendirmelerin yapılması, iş birliği ve iş ortaklıklarının desteklenmesi, alt ve üst yapı çalışmalarının tamamlanması gerektiği sonucuna varılmıştır. Bu noktada sağlık turizminin oluşturabileceği muhtemel risk ve olumsuz etmenler de en aza indirilmiş olacaktır. Gerek bölge bazında gerek ülke bazında sağlık turizminin geliştirilmesi, yerel halkın yaşam standartlarını yükseltecektir. Bu noktada Muğla, hem uluslararası hem de ulusal bağlamda etkin ve kaliteli bir sağlık turizmi hizmeti sunabilecektir.

Araştırma sonucu doğrultusunda Muğla ilinde sağlık turizminin ilerlemesine ve sistemli hale getirilmesine yönelik geliştirilen öneriler aşağıda sıralanmaktadır.

- İş birliği için bir üst yapı geliştirilmesi: Sağlık turizmi paydaşlarının çalışmalarını hem bütüncül hem de birbirlerini destekleyici şekilde yapabilmeleri ve sağllk turizmini geliştirebilmeleri açısından iş birliğine yönelik konfederatif bir kurum kurulabilir. Oluşturulan bu üst yapı kurumların bölgede sağlık turizmini geliştirmesine katkı sağlarken aynı zamanda ortak tanıtım ve reklam çalışmaları yapmaya imkân verebilir. Ayrıca sağlık 
turizmi konusunda dünya kültürüne Muğla ilini daha kapsamlı olarak göstererek bölgenin yerel ölçekte de gelişmesine katkı sunabilir.

- Tanıtım faaliyetlerinin planlanması: Sağlık turizmi temasına yönelik yapılacak tanıtım faaliyetleri neticesinde Muğla ilinin sağlık turizmi potansiyeli arttırılabilir.

- Altyapı eksiklerinin giderilmesi ve iyileştirilmesi: Sağlık kurum ve kuruluşlarına ulaşım ve sağlık turizmi faaliyetlerinin gerçekleştirilmesine uygun konaklama tesisleşmesini sağlamak üzere yapılacak altyapı faaliyetleri neticesinde bölge cazibe merkezi haline getirilebilir.

- İnsan kaynaklarının nitelik ve nicelik açısından geliştirilmesi: Sağlık turizmi alanında eğitimli personel yetiştirilmesi, yabancı dilin geliştirilmesine öncelik verilmesi insan kaynakları alanında nitelikli bir yapıya kavuşmanın temel adımlarından biri olabilir.

- Destinasyonun cazibesini arttıracak uygulamaların geliştirilmesi: Sağlık turizmi kapsamında avantajlı fiyatlarla bölgenin zenginliklerinden faydalanmak isteyen kişilere uluslararası sigorta anlaşmaları yapılarak bu bölgeyi tercih etmeleri sağlanabilir.

- İleri yaş turizmine yönelimin desteklenmesi: Sağlık turizmi kapsamında sadece medikal turizm için değil görece daha az teknik ekipman ve personel gerektiren ileri yaş turizmine yönelik planlamaların yapılması sağlık turizminin daha düşük maliyetlerle gelişimini sağlayabilir.

- Spa-Wellnes turizmine yönelimin desteklenmesi: Bölgede yer alan termal turizm altyapısını teşkil eden kaplıca ve ılıcaların sağlık turizmi kapsamında değerlendirilmesine yönelik yatırımlar yaparak, termal turizmi alanında da bölgeye sağlık turisti çekimi sağlanabilir.

- Turizm işletmelerinin sağlık turizmi kapsamında etkinleştirilmesinde spa-wellness faaliyetlerinin artması: Bölgede var olan oteller ve spa merkezleri aracilığıla spa-wellness turizm faaliyetlerine güç katılabilir.

- Üniversitelerin ilgili birimlerinde sağllk turizmi alanında lisansüstü programlara yer verilmesi: Turizm İşletmeciliği, Sağlık Yönetimi gibi sağlık turizmi ile doğrudan ilgili olabilecek ana bilim dallarında sağlık turizmi alanında verilecek lisansüstü eğitim, kalifiye işgücünün yetişmesine ve sağlık turizmine ilişkin stratejik yönetim anlayışının gelişimine katkı sağlayabilir.

Uygulamaya yönelik bu önerilerin yanı sıra sağlık turizmi konusunda çalışmak isteyen araştırmacılara ve akademisyenlere yönelik öneriler aşağıda sıralanmaktadır:

- Farklı paydaşlardan sağlık turizmine ilişkin farklı soruların yanıtlarını bulmaya yönelik nitel araştırmaların yapılabilir. Bölgeye sağlık turizmi kapsamında gelen turistlerle görüşmeler yapılıp, sağlık turizminin ilerlemesi ve beklentileri karşılamak adına turistlerden fikirleri alınabilir.

- Muğla ilinde farklı paydaşların görüşlerinin daha kapsamlı ve yaygın bir şekilde alınabilmesine yönelik nicel araştırmalar yapılabilir. Nitel araştırmalarda elde edilen sonuçlar ışığında sağlık turizmi konusunda farklı paydaşlardan daha kısa sürede ve daha fazla sayıda veri toplayarak değerlendirilmesini sağlayabilecek ölçek geliştirme ve uygulamaya yönelik araştırmalar gerçekleştirilebilir.

- Sağlık turizmi konusunda daha etkin role sahip farklı destinasyonları inceleyen veya destinasyonlar arası karşılaştırmalar içeren araştırmaların yapılabilir. Ulusal veya uluslararası anlamda sağlık turizmi faaliyetlerinde daha etkin olan Antalya ve İstanbul gibi destinasyonlara yönelik araştırmaların yanı sıra, bu destinasyonlar arasında sağlık turizminin 
uygulanma biçimi, gelişimi vb. farklı başlıklarda karşılaştırmalar içeren araştırmalar gerçekleştirilebilir.

Araştırmada evrenin tamamına ulaşılamadığı için araştırma, görüşleri alınan örneklem ile sınırlıdır. Araştırma verilerinin yalnızca Muğla ili sağlık turizmi paydaşlarının görüşlerinden oluşması nedeniyle farklı destinasyonlar için genelleme yapılması söz konusu değildir. Gelecek araştırmalarda Muğla ilinde farklı paydaşların görüşlerinin daha kapsamlı ve yaygın bir şekilde alınabilmesine yönelik nicel araştırmaların yapılması, sağlık turizmi konusunda daha etkin role sahip farklı destinasyonları inceleyen veya destinasyonlar arası karşılaştırmalar içeren araştırmaların yapılması önerilmektedir.

\section{KAYNAKÇA}

Akdeve, E., Gedik-Balay, İ. ve Barca, M., (2013). Türkiye Sağlık Turizm Sektörünün Analizi Ve Strateji Önerileri. İşletme Araştırmaları Dergisi, 5(3), 64-92.

Akdoğan, H. ve Hiçyorulmaz, E. (2018). Sağlık Turizminin Turizm Faaliyetleri İçerisindeki Yeri Ve Önemi. Uluslararası Sağlık Yönetimi ve Stratejileri Araştırma Dergisi, 4(2), 122-132.

Akdu, U., Karakaş D., Çelik E., Zurnacı J. ve Tabu Ö., (2018). Turizm Rehberliğinde Alan Uzmanlığı Önerisi: Sağlık Turizmi Rehberliği, Turist Rehberliği Dergisi, 1 (2), 124-138.

Aslan, Z. (1996). Ege Bölgesi'ne Yönelik Termal Turizm Talebinin Analizi Ve Termal Turizm İşletme Modeli, Yayınlanmamış Yüksek Lisans Tezi, Dokuz Eylül Üniversitesi, İzmir.

Aydın, R. ve Yılmaz, E. (2020). Medikal Turizmin Kadın Sağlığı Üzerine Etkisi. Journal of Applied Tourism Research, 1(1), 45-52.

Büyüközkan G., Mukul, E. and Kongar, E. (2021). Health tourism strategy selection via SWOT analysis and integrated hesitant fuzzy linguistic AHP-MABAC approach. Socio-Economic Planning Sciences, 74 .

Carrera, P. M. and Bridges, J. F. (2006). Globalization and healthcare: understanding health and medical tourism. Expert Review of Pharmacoeconomics \& Outcomes Research, 6(4), 447-454.

Cohen, E. (2008). Medical tourism in Thailand, AU-GSB e-Journal,1(1), 24-37.

Çeti, B. and Ünlüönen, K. (2020). Economic Evaluation of Health Tourism in Turkey, İstanbul Üniversitesi Journal of Tourismology, 6(1), 99-109.

Çetinkaya, T. ve Zengin, B. (2009). Yaşlı Bakımı ve Turizm. Panel Bildiri Kitapçığı, (1), 72-81.

Çiçek, D. ve Kozak, N. (2012). Anatolia: Turizm Araştırmaları Dergisi'nde Yayımlanan Hakem Denetimli Makalelerin Bibliyometrik Profili, VI. Lisansüstü Turizm Öğrencileri Araştırma Kongresi, Kemer, Antalya, 26 (4), 196-211.

Daştan, İ. (2014). Türkiye'de Sağlık turizmi: Türkiye ve Özelinde İzmir'de Sağlık Turizminin Mevcut Durum Analizi Ve Strateji Önerileri. Mehmet Akif Ersoy Üniversitesi Sosyal Bilimler Enstitüsü Dergisi, 6(10), 143-163.

Demirel, G. ve Ünal, A. (2011). Sağlık Turizmi İşletmelerinden Yararlanan Müşterilerin Beklentilerinin Belirlenmesine Yönelik Bolu İlinde Bir Araştırma, Electronic Journal of Vocational Colleges, December/Aralık, 134-145.

Dryglas, D. and Salamaga, M. (2018). Segmentation by Push Motives in Health Tourism Destinations: A Case Study of Polish Spa Resorts. Journal of Destination Marketing \& Management, 9, 234-246. 
Dünya Turizm Örgütü (World Tourism Organization) (2018 Dec 27). Exploring health tourism. https://www.unwto.org/global/publication/exploring-health-tourism [Erişim Tarihi: 10.02.2021].

Dünya Turizm Örgütü ve Avrupa Seyahat Komisyonu (World Tourism Organization and European Travel Commission) (2018 Dec 20). UNWTO/ETC Launch Report on Health Tourism. http://www2.unwto.org/press-release/2018-12-20/unwtoetc-launch-report-healthtourism [Erişim Tarihi: 10.02.2021].

Edinsel, S. ve Adıgüzel, O. (2014). Türkiye'nin Sağlık Turizmi Açısından Son Beş Yıldaki Dünya Ülkeleri İçindeki Konumu Ve Gelişmeleri, Çankırı Karatekin Üniversitesi İktisadi ve İdari Bilimler Fakültesi Dergisi, 4 (2), 167-190.

Elsaied, H. H., Mahmood, S. A. ve Toprak, L. ( 2014). Turizmin Yükselen Trendi: Sağlık Turizmi ve Güneydoğu Anadolu Bölgesi Örneği, Electronic Journal of Social Sciences, 13 (50), 38-57.

Erdoğan, M. (2018). Kamu Sağllk Politikalarında Yeni Bir Açılım Sağlık Turizmi: SDÜ Hastanelerinde Çalışan Hekimlerin Sağlık Turizmi Farkındalığı Üzerine Bir Araştırma, Yayınlanmamış Yüksek Lisans Tezi, Süleyman Demirel Üniversitesi, Isparta

Esfahani, S.S., Ridderstaat, J. and Öztürk, A.B. (2020). Health Tourism in a Developed Country with a Dominant Tourism Market: The Case of the United States' Travellers to Canada. Current Issues in Tourism, 24 (4), 536-553.

Garcia-Altes, A. (2005). The Development of Health Tourism Services. Annals of Tourism Research, 32(1), 262-266.

Gençay, C. (2007). Sağllk Turizmi, Sürdürülebilir Rekabet Avantajı Elde Etmede Turizm Sektörü, İstanbul: Kazancı Hukuk Yayınevi.

Goodrich, J. N. (1994). Health Tourism: A New Positioning Strategy for Tourist Destinations. Journal of International Consumer Marketing, 6(3-4), 227-238.

Gray, H. H. and Poland S. C. (2008). Medical Tourism: Crossing Borders to Access Health Care, Kennedy Institute of Ethics Journal, 18 (2), 193-201.

Guba, E. G. and Lincoln, Y. S. (1994). Competing Paradigms in Qualitative Research. Handbook of Qualitative Research, 2(105), 163-194.

Gustavo, N. S. (2010). A 21st Century Approach to Health Tourism Spas: The Case of Portugal. Journal of Hospitality and Tourism Management, 17(1), 127-135.

Gülen, K. G. ve Demirci, S. (2012). Türkiye'de Sağlık Turizmi Sektörü, İstanbul: İstanbul Ticaret Odası Yayınları.

Hall, C. M. (1992). Adventure, Sport and Health Tourism. London. Belhaven Press.

Hofer, S., Honegger, F. and Hubeli, J. (2012). Health Tourism: Definition Focused on the Swiss Market and Conceptualisation of Health(i)ness. Journal of Health Organization and Management, 26(1), 60-80.

Işık, M., Özsezer, Y. and Işık, F. (2021). The Current Growth Effect of Health Tourism Market Development in Turkey for the Evaluation on Current Account Deficit. Pearson Journal of Social Sciences \& Humanities, 6 (11), 220-240.

Jònàs-Berki, M., János C., Andrea P. and Antal, A. (2015). A Market and Spatial Perspective of Health Tourism Destinations: The Hungarian Experience. International Journal of Tourism Research, $17,602-612$. 
Kabukcuoğlu, S., (2013). Nevşehir İli Kozaklı İlçesindeki Sağlık Turizmi Potansiyeli Ve Bu Potansiyeli Artırabilmek İçin Yapılabilecekler, Yayınlanmamış Yüksek Lisans Tezi, Beykent Üniversitesi, Nevşehir.

Kangas, B. (2010). Traveling for Medical Care in a Global World, Medical Anthropology, 29 (4), 344362.

Kara, T. (2020). Health Tourism and Concept Complexity of Health Tourism in Turkey, Int Journal of Health Manag. and Tourism, 5(3), 264-290.

Majeed, S., Lu, C. and Javed, T. (2017). The Journey from Allopatic To Naturel Treatment Approach: A Scoping Review of Medical Tourism and Health Systems. European Journal of Integrative Medicine, 16, 22-32.

Manna, R., Cavallone, M., Vincenza Ciasullo, M., Palumbo, R. (2019). Beyond the Rhetoric of Health Tourism: Shedding Light on the Reality of Health Tourism in Italy. Current Issues in Tourism, 23 (14), 1805-1819.

Marlowe, J. and Sullivan, P. (2007). Medical Tourism: The Ultimate Outsourcing. HR Human Resource Planning, 10th International Conference on Knowledge, Economy and Management; 11th International Conference of the ASIA Chapter of the AHRD \& 2nd International Conference of the MENA Chapter of the AHRD, 30, 8-10.

Mikail, E. H. ve Çora, H. (2020). Örgüt İkliminin Özel Sağlık Sektöründe Hizmet Kalitesi Üzerine Yansımalarına İlişkin Bir Çalışma. Turkish Studies, 15(1), 481-498.

Mueller, H. and Kaufmann, E. L. (2001). Wellness Tourism: Market Analysis of a Special Health Tourism Segment and Implications for the Hotel Industry. Journal of Vacation Marketing, 7(1), 517.

Muğla İl Kültür ve Turizm Müdürlüğü. https://mugla.ktb.gov.tr/ [Erişim Tarihi: 10.02.2021].

Özgül, A. (2014). Türkiye'de Sağlık Turizmi Politikaları Üzerine Bir Değerlendirme, Yayınlanmamış Yüksek Lisans Tezi, Süleyman Demirel Üniversitesi, Isparta.

Özsarı, S. H. ve Karatana, Ö. (2013). Sağlık Turizmi açısından Türkiye'nin Durumu. Kartal Eğitim ve Araştırma Hastanesi Tıp Dergisi, 24(2).

Pollock, A. and Williams, P. (2000). Health Tourism Trends: Closing the Gap between Health Care and Tourism. In: W.C. Gartner and D.W. Lime (Eds). Trends in Outdoor Recreation, Leisure and Tourism, CABI Publishing, UK.

Sağlık Bakanlığı (2018). Sağlık Turizmi Hakkında: Türkiye'de Sağlık Turizmi. http://saglikturizmi.gov.tr/TR,175/saglik-turizmi-hakkinda.html. [Erişim Tarihi: 10.03.2021].

Sağlık Turizmi Dairesi Başkanlığı (2010). https://saglikturizmi.saglik.gov.tr/siteagaci [Erişim Tarihi: 10.03.2021].

Sarışık, M. (1994). Türkiye'de Termal Turizmi ve Sandıklı (Afyon) Bölgesi Örneği, Yayınlanmamış Yüksek Lisans Tezi, Akdeniz Üniversitesi, Antalya.

Shelton E. J. and Tucker H. (2005) Tourism and Disability: Issues Beyond Access, Tourism Review International, 8 (3), 205-220.

Smith, M. and Puczko, L. (2008). Health and wellness tourism. Elsevier, USA.

Sülkü, S. N. (2017). Sağlık Turizminde Türkiye'nin Dünyadaki Yeri ve Potansiyeli, Uluslararası İktisadi ve İdari Bilimler Dergisi, Özel Sayı 1, 99-113. 
Şahin, Ö. ve Şahin, M. (2018). Türkiye'de Sağlık Turizminin Potansiyeli ve Geleceği: SWOT Analizi, Journal of Awareness, 3 (5), 287-300.

Tengilimoğlu, D. (2013). Sağlık turizmi: Tedavi Amaçlı Turizm ve Termal Turizmde Sorunlar ve Çözüm Önerileri, Hastane Dergisi, 34(90-96), 51-72.

Tontuş, H.Ö. (2019). Dünyada Sağllk Turizmi. SATURK, http://www.saturk.gov.tr/images/pdf/tyst/02.pdf [Erişim Tarihi: 15.03.2021].

Türkiye Sağllk Turizm Rehberi (2009). Türkiye Sağllk Turizm Rehberi. https://docplayer.biz.tr/768565-Turkiye-saglik-turizmi-rehberi.html [Erişim Tarihi: 15.02.2021].

Ulusal Tez Merkezi (2019). https://tez.yok.gov.tr/UlusalTezMerkezi/tezSorguSonucYeni.jsp [Erişim Tarihi: 10.06.2019].

Uluslararası Resmi Seyahat Birliği (International Union of Official Travel Organisation - IUOTO) (1972) Health tourism. Codis. http://codis4u.wikifoundry.com/page/IUOTO+\%28International+Union+of+Official+Travel+Org anisation\%29 [Erişim Tarihi: 10.05.2019].

Uygun, M. (2018). Türkiye'de Sağlık Turizmi Alanında Paydaş Analizi: Ankara'da Sosyal Ă̆ Analizi Yaklaşımı Uygulaması, Yayımlanmamış Doktora Tezi, Yıldırım Beyazıt Üniversitesi Sosyal Bilimler Enstitüsü, Ankara.

Yalçın, B. (2013). Antalya İli Sağlık Turizmi Potansiyeli Araştırması. Yayınlanmamış Doktora Tezi, Akdeniz Üniversitesi, Antalya.

Yıldırım, A. ve Şimşek, H. (2016). Sosyal Bilimlerde Nitel Araştırma Yöntemleri, (10.Basım) Ankara: Seçkin Yayıncılık.

Yirik, Ş. (2014). Sağlık Turizmi Üzerine Antalya Destinasyonunda Bir Araştırma, Yayınlanmamış Doktora Tezi, Akdeniz Üniversitesi, Antalya. 